This document is confidential and is proprietary to the American Chemical Society and its authors. Do not copy or disclose without written permission. If you have received this item in error, notify the sender and delete all copies.

\title{
Reaction pathways towards the formation of bastnäsite: replacement of calcite by rare earth carbonates.
}

\begin{tabular}{|r|l|}
\hline Journal: & Crystal Growth \& Design \\
\hline Manuscript ID & cg-2020-01313t.R2 \\
\hline Manuscript Type: & Article \\
\hline Author: & n/a \\
\hline & $\begin{array}{l}\text { Complete List of Authors: } \\
\text { Szucs, Adrienn Maria; Trinity College Dublin, Department of Geology } \\
\text { Oavis, Seana; Trinity College Dublin } \\
\text { Rodríguez Blanco, Juan Diego; Trinity College Dublin, Department of } \\
\text { Geology }\end{array}$ \\
\hline
\end{tabular}

\section{SCHOLARONE Manuscripts}


1 Reaction pathways towards the formation of bastnäsite: replacement of calcite by rare 2 earth carbonates.

4 Adrienn Maria Szucs ${ }^{1,}{ }^{2}$, Alexandra Stavropoulou ${ }^{1}$, Claire O'Donnell ${ }^{1}$, Seana Davis ${ }^{1}$, Juan

5 Diego Rodriguez-Blanco 1,3

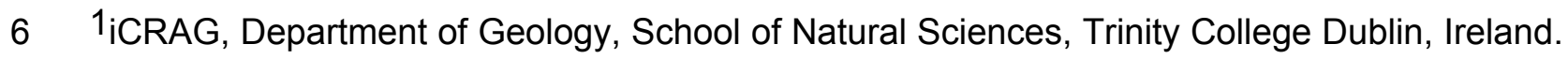
7 2szcsa@tcd.ie; 3J.D.Rodriguez-Blanco@tcd.ie

\section{Abstract}

The interaction of rare earth bearing ( $\mathrm{La}, \mathrm{Nd}, \mathrm{Dy})$ aqueous solutions with calcite crystals at 11 ambient and hydrothermal conditions $\left(25-220^{\circ} \mathrm{C}\right)$ results in the solvent-mediated surface precipitation and subsequent pseudomorphic mineral replacement of calcite by rare earth carbonates. The newly formed rare earth carbonates follow the crystallisation sequence 14 lanthanite $\left[\mathrm{REE}_{2}\left(\mathrm{CO}_{3}\right)_{3} \cdot 8 \mathrm{H}_{2} \mathrm{O}\right] \rightarrow$ kozoite [orthorhombic $\left.\mathrm{REECO} \mathrm{C}_{3}(\mathrm{OH})\right] \rightarrow$ hydroxylbastnäsite 15 [hexagonal $\mathrm{REECO}(\mathrm{OH})$ ]. The specific rare earth involved in these processes and the temperature have strong control of the polymorph selection, crystallisation pathways and kinetics of mineral replacement. Kozoite-(La, Nd), grows oriented onto the calcite surface, forming an epitaxy. This phase forms elongated crystals on [100], with the $\{011\}$ and $\{0-11\}$ as major forms. The epitaxial relationship is $(104)[010]_{\mathrm{cc}} \|(001)[100]_{\mathrm{koz}}$ and is strongly dependent on the ionic radius of the rare earth in the structure of kozoite. These results have strong 21 implications for the understanding of the mineralisation reactions occurring in rare earth 22 bearing deposits, like carbonatite deposits, the most important resources of rare earths in the 23 world. 


\section{Introduction}

Rare-earth elements (REEs) comprise the fifteen elements corresponding to the lanthanides, which are fundamental strategic raw materials to maintain our daily life by providing hightechnology devices, such as mobile phones, computers, batteries ${ }^{1}$. REEs are widely used in civilian and military defence industries; magnets, catalysts, ceramics, glass and electronics require REEs for their production ${ }^{1}$. Most of the renewable energy technologies contain REEs - electric vehicles, solar cells, generators of wind turbines have at least one of the rare-earth elements ${ }^{1-3}$.

Due to their essential role in our modern life, the demand for REEs is continuously growing, pressuring the mining industry to fulfil these needs. Despite their name, REEs can be found in a considerable amount in the Earth's crust, except promethium which is radioactive with a halflife of 17.7 years and therefore much more scarce compared to other REEs. Lanthanum and cerium are just as abundant as copper ${ }^{4}$. In fact, REEs are more abundant than many of the platinum group metals ${ }^{5}$. However, minable deposits are hard to locate with concentrations high enough for economical extraction ${ }^{6}$. The biggest REEs provider is China, followed by Australia, Russia, India, Brazil, Vietnam and the United States. China supplies more than $80 \%$ of the REEs, thus, to avoid their monopoly there is a constant interest in finding alternative REEs ores, especially since 2010 , when China gained almost absolute control above the REE market prices, by providing $95 \%$ of REE production globally ${ }^{1,4}$.

Most of the research nowadays aim to find new REEs sources, while others target to develop cost-efficient recycling methods from waste. In particular, recycling of e-waste (electronic and/or industrial waste) has been gaining broad interest in EU, China and India ${ }^{7-12}$. Less than $20 \%$ of the e-waste is predicted to be recycled and documented, while the rest $(80 \%)$ is deposited without further treatment ${ }^{13}$. For example, in the United States, approximately 50 million metric tons of e-waste is deposited annually, and only $12.5 \%$ of this is recycled ${ }^{14}$. On the other hand, basically, every possible source is considered for potential REEs extraction. 
51 For example, Menéndez et al. ${ }^{15}$, recently suggested the possibility of REEs extraction from palaeosoils in Gran Canaria, Spain. In India, beach placer deposits are targeted as an alternative source ${ }^{16}$. Besides, coal fly ash - which up until now was considered as a waste material- has also been studied for potential REE extraction ${ }^{17}$. Also, sedimentary phosphate deposits ${ }^{18}$ have been found to be enriched in REEs, and specifically, REE-bearing francolite (C-rich fluorapatite) has also been investigated as a source ${ }^{19-21}$. Other interesting potential sources are deep ocean sediments containing polymetallic nodules ${ }^{22,23}$, ferromanganese crusts ${ }^{24}$ and deep-sea mud ${ }^{25}$. Moreover, the Moon and Mars ${ }^{26}$ have been considered as possible long-term REE source in order to meet the future demand of humanity for rare-earth elements. Just the simple consideration of the off-Earth mining shows how critical it is to find a way to extract the needed amount of REEs.

Current methods of REE extraction and refinement are very expensive, both financially and environmentally ${ }^{27}$. Typically, REEs are mined from open pits, underground mines, or leached in situ, and the extraction consumes more water and energy than any other metal ${ }^{28}$. Carbonatites, igneous rocks containing $>50 \%$ carbonate, are the primary deposits of REEs ${ }^{29}$. The main sources of rare-earth elements are the REE-bearing minerals bastnäsite $(\mathrm{REE}) \mathrm{CO}_{3}(\mathrm{~F}, \mathrm{OH})$ and apatite $\mathrm{Ca}_{5}\left(\mathrm{PO}_{4}\right)_{3}(\mathrm{OH}, \mathrm{F}, \mathrm{Cl})$ (where part of the $\mathrm{Ca}$ can be replaced by $\mathrm{REE}, \mathrm{Na}, \mathrm{Sr}$, and $\mathrm{Mn})^{30}$. Following this, monazite $\left(\mathrm{REEPO}_{4}\right)$, xenotime $\left(\mathrm{REEPO}_{4}\right)$, loparite [(Na, REE) $\left.\mathrm{Ti}_{2} \mathrm{O}_{6}\right]$, and lateritic ion-adsorption clays are the most important REE sources ${ }^{31,32}$.

70 These ores have magmatic, hydrothermal and/or metamorphic origin, while other ores are

71 formed by erosion and weathering (mostly laterites and bauxites) and serve as secondary 72 deposits ${ }^{1}$. Carbonatites contain a complex set of carbonate minerals (e.g. calcite, dolomite, 73 strontianite, siderite) and other accessory minerals such as iron-oxides or phosphates and the 74 REE-bearing minerals (e.g., monazite, apatite, bastnäsite) as well ${ }^{33,34}$. These deposits are 75 dominated by the four light REE (LREE, La, Ce, $\mathrm{Pr}, \mathrm{Nd}$ ) and contain minor concentrations of 76 heavy REE (HREE); however, REEs behave incompatibly throughout igneous differentiation 77 of carbonatites. In alkali-free carbonatites, the REEs are concentrated in potentially economic 
domains within the carbonatites and are hosted by relatively insoluble REE carbonate and phosphate minerals. Conversely, alkali-bearing carbonatites exsolve REE-rich fluids which migrate long distances, keeping high REE solubilities. As a consequence, $\mathrm{Na}$ and $\mathrm{K}$ produce higher HREE/LREE ratios in the transported fluids, but K-rich fluids tend to transport HREE relative to Na-rich fluids ${ }^{35}$. Also, recent thermodynamic calculations suggest that the main ligands responsible for the transport of $\mathrm{REE}$ at hydrothermal conditions are $\mathrm{Cl}^{-}$and $\mathrm{SO}_{4}{ }^{2-}$, while $\mathrm{F}^{-}$is a depositional ligand that reduces the range of conditions for which REE can be stabilised in hydrothermal solutions ${ }^{36-39}$.

Rare earth elements have a known affinity for carbonates not just in natural but in experimental settings. Experimental work has demonstrated that rare earths adsorb on the surface of carbonate minerals ${ }^{40,41}$ and that they are strongly partitioned into these minerals, substituting for $\mathrm{Ca}^{2+} 40,42-50$. However, little is known about the fundamental physicochemical conditions governing the mobility and transport of REE at hydrothermal conditions in the presence of carbonate minerals.

As REEs are essential raw materials for emerging renewable energy resources, we are urged to obtain and use them in a sustainable manner to maintain current standards of living and ensure the quality of life for future generations. This will require continued research on REEbearing mineral formation to better understand the geological processes by which these elements are concentrated. One of the major problems related to exploration and exploitation of rare-earth elements in carbonatites is the lack of understanding of the crystallisation mechanisms and pathways of REE carbonates and in particular their early stages of formation. In fact, carbonatite deposits are complex systems which are affected by several parameters (e.g., temperature, pressure, chemistry of solids and fluids). Due to this complexity of the participating factors, understanding the origin and all the mechanisms of formation of REE deposits involved in a complete system requires a deep understanding of the mineral-fluid reactions that drive the crystallisation and dissolution of carbonates in REE-bearing hydrothermal solutions. This includes, but does not limit to, direct nucleation from hydrothermal 
105 fluids, surface crystallisation, coprecipitation, or mineral replacement reactions. Many of these 106 reactions in carbonate systems can be rapid, complex and multi-step, involving short-lived 107 intermediate phases ${ }^{51}$, requiring step-by-step analysis under well-defined laboratory 108 conditions. Therefore, our work has focused on the interaction of calcite $\left(\mathrm{CaCO}_{3}\right)$ and three 109 REE (La, Nd, and Dy) in solution at low hydrothermal conditions $\left(21-220^{\circ} \mathrm{C}\right)$. These three REE 110 have been selected because of the balance between their chemical similarities and 111 dissimilarities. La and $\mathrm{Nd}$ both belong to the group of LREE, while Dy is classified as HREE. 112 There are slight contrasts in their chemical properties, like their ionic radii: $\mathrm{La}^{3+}, \mathrm{Nd}^{3+}$ and $\mathrm{Dy}^{3+}$ 113 average ionic radii are $1.15,1.08$ and $0.99 \AA$, respectively, values close to the radii of $\mathrm{Ca}^{2+}$ $114(0.99 \AA)$ and $\mathrm{Sr}^{2+}(1.13 \AA)^{52,53}$. In addition, the U.S. Department of Energy identified Nd as 115 critical element for both short and long term. Among all the REEs, Dy is labelled as the most 116 critically needed rare-earth element ${ }^{54,55}$.

117 In this study, the effects of the interaction of REE-rich aqueous hydrothermal solutions with 118 calcite crystals were investigated with the purpose of mimicking potential recrystallisation or 119 replacement reactions involving calcite in REE deposits during hydrothermal and metasomatic 120 processes. In particular, our objectives were to determine (1) the fate of REE during these 121 interaction processes, (2) the nature of potential newly formed phases as a function of aqueous chemistry and temperature, (3) the mechanisms and kinetics of crystal formation.

\section{Methods}

125 The general experimental procedure consisted of adding $0.05 \mathrm{~g}$ ( 0.5 millimoles) of calcite crystals (Iceland spar variety) with sizes of $0.5-1.0 \mathrm{~mm}$ to $50 \mathrm{~mL}$ of $10 \mathrm{mM}$ rare earth bearing

127 aqueous (MilliQ) solutions $(\mathrm{pH} \approx 5.4$; Ca/REE molar ratio of $\sim 1)$. Also, some additional 128 experiments with an excess of calcite (e.g., $0.30 \mathrm{~g}$ ) were carried out to exhaust the REE during the reaction process. Solutions containing one single rare earth element were prepared using 
$130 \mathrm{La}\left(\mathrm{NO}_{3}\right)_{3} \cdot 6 \mathrm{H}_{2} \mathrm{O}, \mathrm{Nd}\left(\mathrm{NO}_{3}\right)_{3} \cdot 6 \mathrm{H}_{2} \mathrm{O}$ and $\mathrm{Dy}\left(\mathrm{NO}_{3}\right)_{3} \cdot 6 \mathrm{H}_{2} \mathrm{O}$ reagents (Sigma Aldrich; $99.99 \%$ trace 131 metals basis). Experiments were carried out in $50 \mathrm{~mL}$ teflon-lined stainless-steel autoclaves at 132 different temperatures $\left(21,50,95,160\right.$ and $\left.220^{\circ} \mathrm{C}\right)$ and saturated water vapor pressures. Solid 133 samples were carefully extracted at increasing time intervals and then placed in an oven at 50 $134{ }^{\circ} \mathrm{C}$ during $30 \mathrm{~min}$ for drying.

135 Samples were preliminarily examined using a binocular lens (ZEISS SteREO Discovery.V8 136 with 8:1 Manual Zoom Range; 6.3-50.4 X) to determine any large visible changes in the 137 morphology and colour of calcite crystals. Then, the samples were characterised with powder 138 X-ray diffraction (XRD) for the identification and quantification of any newly formed crystalline 139 compounds. Conventional powder XRD patterns were collected using a Bruker D5000 powder $140 \mathrm{X}$-ray diffractometer (Cu Ka radiation, $0.01^{\circ} \mathrm{step}^{-1}$ from 5 to $60^{\circ} 2 \theta$ at $1^{\circ} \mathrm{min}^{-1}$ ). Identification 141 of crystalline phases was carried out with the Diffract Suite EVA software from Bruker in 142 combination with the Powder Data File (PDF-4, The International Centre for Diffraction Data). 143 Pattern-matching refinement and quantification of crystalline phases were carried out with the 144 Rietveld refinement software TOPAS ${ }^{56}$.

145 Scanning electron microscopy (SEM) was used to characterise the changes in the morphology 146 of calcite, potential newly formed phases, and to obtain elemental analysis of areas of interest. 147 All samples were carbon-coated and placed into a Tescan MIRA XMU FE-SEM operating 148 under high vacuum conditions and equipped with an Oxford Instruments NanoAnalysis X- Max $14980 \mathrm{~mm}^{2}$ Energy Dispersive Spectroscopy (EDS) detector running Oxford Instruments 150 NanoAnalysis AZtecTimed analysis software. Analyses were performed using an accelerating 151 voltage of $20 \mathrm{kV}$ and a beam current of $300 \mathrm{pA}$.

152 Lastly, the saturation indexes of solid phases during the equilibration of the REE-bearing 153 aqueous solutions with respect to calcite were calculated with the hydrogeochemical code 154 PHREEQC ${ }^{57}$ using the LLNL database and the solubility products of REE-bearing carbonates 155 determined by Essington and Mattigod ${ }^{58}$ and Voigt et al ${ }^{59}$. 


\section{Results}

158 The analysis of solid samples obtained from our experiments revealed that the interaction of 159 calcite with rare earth bearing solutions was translated into the formation of a series of surface 160 precipitates that partially or totally replaced the host crystals. The combination of powder XRD 161 and SEM-EDS allowed the identification and quantification of newly formed phases, as well as the interpretation of the mechanisms of surface precipitation.

\subsection{Observations in visible light (binocular lenses)}

165 The preliminary observation with binocular lens of solid samples extracted from the La-, Nd166 and Dy-rich solutions at different times and temperatures allowed to gain information on the 167 level of influence of temperature on the crystallisation process. These observations already 168 revealed a series of surface precipitates on the surface of calcite. The presence and the extent 169 of the precipitates varied depending on the temperature and reaction time. At $21{ }^{\circ} \mathrm{C}$, the formation of surface precipitates on calcite took the most prolonged period of time: a precipitate on the surface of calcite was observed after 14 days in the La experiments but took 145 days

172 to form in the $\mathrm{Nd}$ and Dy experiments. In the case of $50^{\circ} \mathrm{C}$ experiments, the formation of a 173 surface crust on calcite in the La-, Nd- and Dy-bearing experiments occurred after 5, 2 and 9 174 days of reaction, respectively. Samples obtained from all experiments at $95{ }^{\circ} \mathrm{C}$ revealed 175 surface precipitates after the first 24 hours of reaction. Finally, at the highest temperatures 176 (160 and $\left.220^{\circ} \mathrm{C}\right)$ thick crusts were observed in all experiments after 24 hours of reaction. In addition to this, changes in the colour and opacity of the calcite grains were observed in all

178 experiments. Calcite (Iceland spar) crystals placed in the aqueous solution were initially 179 transparent and colourless, but they became more translucent with time and were completely 180 opaque at the end of all experiments (e.g., Figure SI-1). After the interaction with La- Nd- and 
181 Dy-bearing solutions, all calcite crystals became light-pink, dark-pink and yellowish, 182 respectively.

\section{Powder X-ray Diffraction}

185 Powder XRD allowed us to identify newly formed secondary minerals. A series of different 186 rare-earth bearing carbonate minerals were detected: La- and Nd-lanthanite $187\left[(\mathrm{REE})_{2}\left(\mathrm{CO}_{3}\right)_{3} \cdot 8 \mathrm{H}_{2} \mathrm{O}\right]$, La-, Nd- and Dy-kozoite, $\left[(\mathrm{REE}) \mathrm{CO}_{3}(\mathrm{OH})\right]$ and La- and $\mathrm{Nd}-$ 188 hydroxylbastnäsite $\left.\left[(\mathrm{REE}) \mathrm{CO}_{3}(\mathrm{OH})\right]\right)$. Powder XRD patterns of these newly formed phases 189 obtained at the end of the experiments are presented in Figures 1-3, and all experimental 190 results are summarised in Table 1. Phase quantification using Rietveld refinement revealed 191 that the kinetics of crystallisation of the secondary REE-bearing minerals and the polymorph 192 selection were controlled by temperature and also by the ionic radius of the rare earth. 193 Regardless of the composition of the newly formed crystals, all calcite grains were fully 194 replaced by crystalline rare earth carbonates at temperatures $\geq 50{ }^{\circ} \mathrm{C}$ (e.g., Figure 4). The 195 kinetics of these replacement reactions were temperature-dependent: in the ambient 196 temperature experiments, the replacement reactions did not complete, with calcite being 197 replaced a maximum of 15 weight $\%$ by the newly-formed phases after 145 days. However, at 19850,95 and above $160^{\circ} \mathrm{C}$, calcite was replaced after 20, 11 and 1 days, respectively. Also, the 199 kinetics of replacement of calcite by secondary phases in the La-bearing experiments was 200 always faster compared to the other two rare earths. Conversely, the onset of crystallisation 201 and the kinetics of replacement for the Dy-bearing experiments were the slowest (Table 1).

202 The interaction of La-bearing solutions with calcite crystals at ambient temperature resulted in 203 the formation of La-lanthanite (PDF 00-014-0190) (Figure 1, bottom) after 14 days of reaction, 204 remaining stable during the full duration of the experiments ( 145 days). At $50^{\circ} \mathrm{C}$ La-lanthanite 205 was not detected at any time and after 5 days La-kozoite (PDF 00-049-0981) crystallised 
206 (Figure 1, middle), remaining stable until the end of all experiments. The evolution of the 207 experiments carried out at $95^{\circ} \mathrm{C}$ was similar, but the onset of the crystallisation of La-kozoite 208 was much faster ( $<1$ day) and only at the very end of the experiment (154 days) minor amounts 209 ( 2 weight\%) of La-hydroxylbastnäsite (PDF 00-026-0815) were found along with La-kozoite. 210 At $160{ }^{\circ} \mathrm{C}$, La-kozoite took >21 days to fully transform to La-hydroxylbastnäsite, while at the 211 maximum temperature studied, $220^{\circ} \mathrm{C}$, only La-hydroxylbastnäsite formed in less than 24 212 hours and no other crystalline phases were observed (Figure 1, top). The experiments 213 performed with Nd-bearing solutions produced similar results to the La counterpart: At ambient 214 temperature Nd-lanthanite (PDF 00-030-0678) was found in the ambient solution experiments 215 after 145 days (Figure 2, bottom). Nd-kozoite (PDF 00-027-1296) was found at 50 and $95{ }^{\circ} \mathrm{C}$ 216 (Figure 2, middle) after 2 and $<1$ days, respectively. At $50{ }^{\circ} \mathrm{C} \mathrm{Nd-kozoite} \mathrm{remained} \mathrm{stable}$ 217 during the full duration of the experiment, while at $95^{\circ} \mathrm{C}$ minor amounts $(<1$ weight $\%)$ of $\mathrm{Nd}$ 218 hydroxylbastnäsite (PDF 00-038-0400) were detected after 154 days (Table 1 ). At $160^{\circ} \mathrm{C}$ only 219 Nd-kozoite fomed but no transformation to $\mathrm{Nd}$ - hydroxylbastnäsite was observed in 28 days. 220 Finally, at $220^{\circ} \mathrm{C} \mathrm{Nd-kozoite} \mathrm{transforming} \mathrm{to} \mathrm{Nd-hydroxylbastnäsite} \mathrm{was} \mathrm{identified} \mathrm{(Figure} \mathrm{2,}$ 221 top), a transformation which was completed after 7 days. Finally, the interaction of calcite with 222 Dy-bearing solutions resulted in the temperature-dependent crystallisation of Dy-kozoite (PDF 223 04-014-4506) (Figure 3 ) after 145 days $\left(21^{\circ} \mathrm{C}\right), 9$ days $\left(50^{\circ} \mathrm{C}\right)$ and $<1$ day $\left(\geq 95^{\circ} \mathrm{C}\right)$. This was 224 the only crystalline phase detected in the Dy-bearing experiments at all temperatures, 225 remaining stable during the full duration of the experiments.

\section{Scanning Electron Microscopy}

228 The SEM images obtained after different periods of the interaction of the calcite grains with 229 the rare earth bearing solutions revealed the formation of precipitates on the surface of calcite. 230 A representative example is presented in Figure 5, which shows the surface of a typical calcite grain after $0.75,1.75$ and 13 days of reaction with a La-bearing parent solution at $95{ }^{\circ} \mathrm{C}$. The 
232 surface of calcite showed clear dissolution signs and started to be covered by small $(\sim 40 \mu \mathrm{m})$ 233 individual crystals with slightly elongated morphologies (Figure 5a). Afterwards, this precipitate 234 began to grow and extend (Figure $5 b$ ) to quickly cover the full surface of calcite forming a crust. 235 The final result was a pseudomorphic replacement in which the original morphology and 236 dimensions of the calcite grains remained constant (Figure $5 c$ ), but the host mineral was fully 237 replaced by the newly formed rare earth carbonates as also revealed by XRD (e.g., Figure 4). 238 SEM images also confirmed that the initiation of the surface precipitation process, the kinetics 239 of the full replacement reaction and the morphology of the secondary minerals (Table 1) were 240 controlled by the temperature and the rare-earth element in the aqueous solution. Results from 241 energy dispersive spectroscopy (EDS) microanalysis of selected crystals supported the 242 chemistry of the newly formed phases already identified with powder XRD, consisting of 243 oxygen and the rare-earth ( $\mathrm{La}, \mathrm{Nd}$ or $\mathrm{Dy}$ ). The content of $\mathrm{Ca}$ in all the newly formed phases 244 was very low (atomic $\% \leq 1$ ) or below the detection limit of the instrument (Table SI-1).

245 Regarding the crystal morphology, the rare-earth bearing carbonates showed very different 246 morphologies. La- and Nd-Lanthanite developed very thin, platy morphologies (Figure 6). La247 Lanthanite formed aggregates fully covering all calcite grains after 14 days of reaction (Figure $2486 a, b)$, with sizes ranging between 10 and $100 \mu \mathrm{m}$, while Nd-lanthanite consisted of 20-50 $\mu \mathrm{m}$ 249 single crystals disseminated on the surface of calcite (Figure $6 \mathrm{c}, \mathrm{d}$ ) that did not even cover the 250 full surface of the host grains after 145 days of reaction. La- and Nd-kozoite had similar sizes $251(10-20 \mu \mathrm{m})$ but while the former consisted of small prisms (Figure 7a and b), the latter had 252 bladed or spindle-shaped morphologies (Figure 7c and d). These two phases, especially Nd253 kozoite, grew oriented onto the calcite surface in most experiments (Figure 7b, c and d) but 254 sometimes also showed random orientation, especially when the replacement reaction was 255 completed. On the other hand, the Dy-kozoite typically precipitated as bow-tie aggregates 256 showing some branching (Figure 7e). These aggregates were on average $50 \mu \mathrm{m}$ long, formed 257 by spindle-shaped individual crystals usually smaller than $25 \mu \mathrm{m}$. The size and morphology of 258 Dy-kozoite crystals at 160 and $220{ }^{\circ} \mathrm{C}$ was different compared to lower temperature 
259 experiments in this system and consisted of tabular and prismatic crystals with sizes smaller 260 than $50 \mu \mathrm{m}$ (Figure 7f). Finally, the highest temperature phases, La-hydroxylbastnäsite and 261 Nd-hydroxylbastnäsite showed similar morphologies (Figure 8): The former crystallised as 262 triangular prisms with sizes usually smaller than $20 \mu \mathrm{m}$ (Figure 8a) and the later consisted of 263 slightly larger $(\sim 40 \mu \mathrm{m})$ rectangular prisms (Figure 8b).

264 SEM observations revealed that the crystallisation of La- and Nd-kozoite on the surface of 265 calcite took place via the formation of individual crystals following a clear non-random 266 orientation (Figure 9a). La- and Nd-kozoite crystals with lengths of $\sim 10 \mu \mathrm{m}$ developed to form 267 an oriented overgrowth on the (104) surface of calcite (Figure 9 b). With time, the calcite 268 surface got completely covered by oriented kozoite crystals and also by crystals with random 269 orientations, most of them formed on the top of the epitaxial overgrowth (Figure $9 \mathrm{c}$ ). Although 270 the initial neoformed crystals of La- and Nd-kozoite exhibited spindle-shaped morphologies, 271 with time these crystals became more elongated and slightly more prismatic, reaching lengths 272 no longer than $\sim 50 \mu \mathrm{m}$. In this epitaxial overgrowth of calcite and kozoite (Figure 10) the [010] 273 direction of calcite and the [100] direction of kozoite are parallel on the epitaxial faces calcite 274 (104) and kozoite (001). La- and Nd-kozoite form elongated crystals on [100], with \{011\} and $275\{0-11\}$ as major forms. An explanation of the epitaxial overgrowth requires further consideration 276 on the atomic arrangement of the structures of calcite and kozoite, which will be discussed in 277 the next section.

\section{4. Discussion}

280 The sorption of dissolved REE at all studied temperatures, mediated by the surface of calcite, 281 occurred via surface precipitation, leading to the subsequent crystal growth of different REE 282 carbonates. The interaction of the REE-bearing solutions and calcite grains led to the release 283 of $\mathrm{Ca}^{2+}$ and $\mathrm{CO}_{3}{ }^{2-}$ from the surface of calcite to the aqueous solution. As the concentration of 
$284 \mathrm{Ca}^{2+}$ and $\mathrm{CO}_{3}{ }^{2-}$ increased with time, especially close to the calcite surface, the carbonate ions 285 reacted with the $\mathrm{REE}^{3+}$ ions in the solution favouring the precipitation different REE carbonate 286 polymorphs. The combination of XRD and SEM data showed that the interaction of calcite with 287 the REE-bearing fluid was always translated into a solution-mediated pseudomorphic 288 replacement of calcite by lanthanite, kozoite or hydroxylbastnäsite. In all cases, a centripetal 289 replacement was observed, in which the calcite grains were replaced from their periphery 290 inwards. This type of replacement takes place because the newly formed phases are less 291 soluble than the host mineral at the P-T range studied. Reports of solubility product of La- and 292 Nd-lanthanite ${ }^{58}$, La- and $\mathrm{Nd}$-kozoite and La- and $\mathrm{Nd}$ - hydroxylbastnäsite ${ }^{59}$, show that 293 lanthanites are 5-6 orders of magnitude more insoluble than calcite ${ }^{60}$ and the difference 294 between calcite and kozoite or hydroxylbastnäsite solubility products is even higher, of 14 and 29516 orders of magnitude, respectively.

296 The evolution of our experiments taken as a whole (Figure 11) revealed the crystallisation 297 sequence started with lanthanite, followed by kozoite and ending with hydroxylbastnäsite, 298 except for these experiments carried out using Dy, in which the Dy-kozoite was the only stable 299 phase. The polymorph selection of REE carbonates during the experiments was temperature300 dependent: lanthanite (highly hydrated compound) formed at ambient temperature, while 301 kozoite and hydroxylbastnäsite (both anhydrous) at temperatures between 50 and $220{ }^{\circ} \mathrm{C}$. 302 However, the polymorph selection was very strongly dependent on the ionic radii of the rare303 earths, also resulting in variations in the dimension of the unit cells of the newly formed crystals 304 (Table 2) and also in some differences in the crystallisation sequences in our three studied 305 REE systems. Our data shows that for each of the isomorphs, lanthanite, kozoite and 306 hydroxylbastnäsite, the largest unit cell parameters correspond to the lighter REE isomorphs, 307 a consequence of the decrease in ionic radii with atomic weight of the REE (lanthanide 308 contraction). This is in agreement with the usual crystal chemistry of these minerals in nature 309 and synthesis experiments. Lanthanite-type isomorphs contain light rare-earths, with larger 310 ionic radius, like $\mathrm{La}, \mathrm{Ce}$ and $\mathrm{Nd}^{61-64}$ forming a structure with two types of RE-O polyhedra in 
311 10-fold and 8-fold coordination. The REE-O coordination in kozoite isomorphs is 10, and these 312 can be synthesized using light and intermediate rare-earths ( $\mathrm{La}, \mathrm{Nd}$, Dy; ${ }^{64-67}$ ). However, 313 heavier REE than Dy do not form kozoite but result into different structures with orthorhombic 314 and tetragonal crystal systems and smaller (8- and 9-fold) RE-O coordination numbers ${ }^{66}$. In 315 hydroxylbastnäsite, the REE-O coordination is 9-fold, forming a hexagonal mineral structure 316 that involves light REE ( $\left.\mathrm{La}, \mathrm{Ce}, \mathrm{Nd} ;{ }^{64,68}\right)$, while the crystallisation of pure hydroxylbastnäsite 317 isomorphs containing heavier REE requires high-pressure conditions ${ }^{69-71}$.

318 This general crystallisation evolution is consistent with a progressive dehydration sequence 319 and also agrees with the sequences observed by Vallina et al. ${ }^{64,67}$ in their homogeneous 320 nucleation experiments performed by mixing carbonate and rare-earth bearing solutions. 321 Vallina et al. ${ }^{64,67}$ crystallisation sequences also included metastable poorly-ordered precursors 322 at the very beginning of the reactions. It is well known that in aqueous systems the driving 323 force required to produce these poorly-ordered precursors prior to crystallisation is a rapid 324 increase in supersaturation levels in the solution ${ }^{51,72}$. In our experiments, no evidence of 325 poorly-ordered precursors were observed at any stage of the experiments. This is interpreted 326 as a consequence of the gradual dissolution of calcite and therefore, lower increase in 327 supersaturation levels in the aqueous solution compared to homogeneous nucleation 328 experiments. On the other hand, and also in agreement with the previous studies, the 329 crystallisation sequence observed proceeded through two transient (metastable) phases, 330 lanthanite and kozoite, prior to the formation of the most insoluble and thermodynamically 331 stable polymorph (hydroxylbastnäsite), a known phenomenon referred to as "Ostwald's Rule 332 of Stages" ${ }^{73}$, observed in many mineral systems (e.g., Bots et al. ${ }^{74}$; Van Driessche et al. ${ }^{75}$ ). 333 The total absence of hydroxylbastnäsite in all the Dy-bearing experiments is a consequence 334 of the smaller size of the $\mathrm{Dy}^{3+}$ ion $(0.99 \AA)$ compared to $\mathrm{La}^{3+}(1.15 \AA)$ and $\mathrm{Nd}^{3+}(1.08 \AA)$, 335 impeding the crystallisation of this phase under our experimental P-T conditions 66.

336 In order to determine the saturation indices (SI) for the REE-bearing carbonates, the activities 337 of the ions in the solution and the solubility products of the solid phases need to be known. 
338 The solubility measurements of some of these REE-bearing carbonates have been carried out 339 at ambient temperature (e.g., Nd-kozoite and La-hydroxylbastnäsite and Nd340 hydroxylbastnäsite ${ }^{59}$ ). However, there is a lack of measurements at higher temperatures due 341 to insufficient data about the stabilities of the aqueous complexes that REE form with 342 carbonates and $\mathrm{OH}^{-}$ions. This is complicated by the great discrepancies in the experimentally 343 calculated solubility products of some of the compounds; e.g., variations of experimentally 344 calculated solubility products of La-Lanthanite differ in 6 orders of magnitude as a result of 345 having used natural samples also containing other REEs (e.g., log K ranging from -29.91 to $34635.45^{58,76,77}$ ). Also, no solubility product has been yet determined for Dy-kozoite.

347 Our PHREEQC calculations show that when the REE-bearing solution is equilibrated with 348 calcite at ambient temperature, it is already highly supersaturated for La-lanthanite (SI>9.0), 349 La-hydroxylbastnäsite (S|>8.5), Nd-lanthanite (S|>10.9), Nd-kozoite $(S \mid>5.9)$ and Nd350 hydroxylbastnäsite (SI>7.4). The saturation indices of the REE-bearing phases are still positive 351 even before equilibrium has been reached for calcite (e.g., $S I_{\text {calcite }}=-5$ ). Therefore, although 352 the calculations correspond to ambient temperature conditions, they show that the formation 353 of the observed REE carbonates is likely to occur during the very early stages of calcite 354 dissolution. Besides, we suggest that the dissolution of a few monolayers of the calcite surface 355 results in a fluid boundary layer that is highly supersaturated to the more stable REE-bearing 356 phases, promoting the formation of surface precipitates. The precipitation of the newly-formed 357 REE carbonates on the surface of calcite would enhance the dissolution rate of calcite, 358 increasing as a consequence the growth rate of the overgrowth ${ }^{78,79}$.

\section{Epitaxial overgrowth}

361 One of the most significant features of the interaction of calcite with the La-bearing and the 362 Nd-bearing aqueous solutions is the oriented overgrowth of newly kozoite formed on the 
363 surface of calcite during the first stages of the replacement reaction (Figures $7 b-d, 9$ and 10). 364 Despite the centripetal replacement resulted in the depletion of all calcite in the experiments, 365 the very early stages of this reaction can be considered as an epitaxy. Figure 12 shows the 366 projections of a (104) slice of calcite and the (001) slice of kozoite. Kozoite grows with its [100] 367 elongation direction following the [010] direction of calcite substrate.

368 A key parameter to understand and quantify the epitaxial relationship between the substrate 369 and the overgrowth is the lattice misfit $(m f)$, which is described using this expression ${ }^{80}$ :

$371 m f(\%)=\frac{t_{[u v w]_{s u b}}-t_{[u v w]_{\text {over }}}}{t_{[u v w]_{\text {over }}}} \cdot 100$

373 where $t_{[u v w]_{s u b}}$ and $t_{[u v w]_{o v e r}}$ correspond to the repeating period along the matching directions $374[u v w]$ of the substrate (calcite) and the overgrowth (kozoite), respectively. For La-kozoite and 375 calcite, the misfit between the $[010]_{\mathrm{cc}} \|[100]_{\mathrm{koz}}$ alignments is only $-0.93 \%$. This misfit is $0.72 \%$ 376 in Nd-kozoite. Also, the misfit between the $[2-21]_{\mathrm{cc}} \|[010]_{\mathrm{koz}}$ is $-5.71 \%$ in La-kozoite and $3774.55 \%$ in Nd-kozoite (Figures 10 and 12). The misfit with a positive value indicates that the 378 matching direction or the Nd-kozoite is very slightly contracted along that [100] direction 379 compared to the unit cell of calcite. The misfits with negative values indicate an expansion of 380 the unit cell of La-kozoite in the [010] and [2-21] directions compared to the unit cell of the 381 calcite substrate. In the case of $\mathrm{Nd}$-kozoite this expansion relative to the unit cell of calcite 382 occurs in the [010] direction. All these values are clearly below the limits of the generally 383 accepted values of misfit (15-20\%) required for an epitaxial overgrowth to occur 81 .

384 One question of interest is to understand why no oriented overgrowth was observed for the 385 Dy-kozoite. In the case of an epitaxial overgrowth of Dy-kozoite on calcite, the misfit values for 386 the $[010]_{\mathrm{cc}} \|[100]_{\mathrm{koz}}$ and $[2-21]_{\mathrm{cc}} \|[010]_{\mathrm{koz}}$ alignments would be $3.09 \%$ and $-4.12 \%$, 
387 respectively. These values are close to the other two kozoite isomorphs and are a direct 388 consequence of the small variations in their unit cell parameters and interatomic distances as 389 a consequence of the different ionic radii of the $\mathrm{REE}^{3+}$ (Table 2). Therefore, although the 390 epitaxial overgrowth of the Dy-kozoite and calcite seems theoretically possible, there are some 391 factors inhibiting this oriented overgrowth. Our hypothesis relies on the mechanism of growth 392 of this phase. Experiments showed two main differences in the crystallisation of Dy-kozoite 393 compared to the La- and Nd-kozoite isomorphs: first, the growth morphology of Dy-kozoite 394 (bow-tie aggregates made of spindle-shaped crystals; Figure 7e,f) is very different compared 395 to La- and Nd-kozoite (Figure 7a-d), showing more single crystals at the beginning of the 396 crystallisation process. Second, the induction time of Dy-kozoite crystallisation was much 397 longer than the La- and Nd-bearing isomorphs. These two differences can be explained taking 398 into account the combined effect of the ionic potential of the REE ${ }^{3+}$ ions ${ }^{52}$. The ionic potential 399 is expressed as the charge of the cation divided by its ionic radius. All ions are solvated in 400 solution and, in order to become part of a crystalline structure, they need to remove their 401 solvation shells. The ionic potential of the $\mathrm{REE}^{3+}$ cation is proportional to its strength to hold 402 the water molecules of the solvation shell ${ }^{52,82}$. Therefore, the higher the ionic potential, the 403 higher the energy needed to remove the solvation layer of the ion and hence the highest the 404 temperature or the longer the time that is required for the crystal nucleation process to begin 405 83. This is a well-known variable that affects the onset of nucleation during the homogeneous 406 crystallisation of REE-carbonates ${ }^{62,64}$ and Ca-Mg carbonates ${ }^{84,85}$. In the case of the REE, the 407 ionic potential of $\mathrm{La}^{3+}$ is $2.60, \mathrm{Nd}^{3+}$ is 2.77 , while the largest value belongs to $\mathrm{Dy}^{3+}, 3.03$. 408 Thereby $\mathrm{Dy}^{3+}$ requires the highest energy (or the longest time) to desolvate before it 409 incorporates into the lattice of the growing crystals. This longer induction time compared to the 410 La- and $\mathrm{Nd}$-bearing experiments allows more time for the release of $\mathrm{Ca}^{2+}$ and $\mathrm{CO}_{3}{ }^{2-}$ ions from 411 the surface of calcite to the aqueous solution, resulting in higher supersaturation levels for Dy412 kozoite. Supersaturation is the driving force for nucleation and growth, and it dictates the 413 mechanism of crystallisation and crystal morphology. The observed morphologies for Dy414 kozoite are consistent with the growth morphologies observed in other carbonate minerals 
415 during spherulitic growth processes, which require high supersaturation conditions (e.g. $41651,64,84,86,87)$. These spherulitic morphologies are a consequence of a rapid (i.e., few minutes) 417 nucleation and growth of new crystals on the surface of already existing crystals via non418 crystallographic branching, resulting in aggregates with orientational defects, as there is no 419 structural relationship between the newly nucleated crystals and the already existing ones ${ }^{88-}$ 42091 . Compared to the La-kozoite and Nd-kozoite isomorphs, the more rapid growth kinetics of 421 Dy-kozoite and the large number of orientational defects would prevent the formation of an 422 oriented overgrowth on the surface of calcite.

423 From a wider perspective, it is essential to highlight that all the kozoite-type isomorphs 424 obtained in our experiments are members of the ancylite mineral group ${ }^{92}$, a group with a large 425 chemical variability. Our experiments had targeted chemistry, and therefore all products only 426 contained a single rare earth element. Also, their $\mathrm{Ca}^{2+}$ content was very low (atomic $\%<1.4$ 427 or below detection limit; Table SI-1). However, some of the members of the ancylite group 428 contain not only rare earth elements, but also divalent cations $\left(\mathrm{Ca}^{2+}, \mathrm{Sr}^{2+}, \mathrm{Pb}^{2+}{ }^{33}\right.$ like ancylite$429(\mathrm{Ce}) \quad\left(\mathrm{CeSr}\left(\mathrm{CO}_{3}\right)_{2}(\mathrm{OH}) \cdot \mathrm{H}_{2} \mathrm{O}\right)^{94}$, ancylite-(La) $\left(\mathrm{LaSr}\left(\mathrm{CO}_{3}\right)_{2}(\mathrm{OH}) \cdot \mathrm{H}_{2} \mathrm{O}\right)^{95}$, several Ca-rich 430 calcioancylites with $\mathrm{Ce}$ and $\mathrm{Nd}{ }^{96,97}$, the $\mathrm{Pb}$-rich gysinite-( $\left.\mathrm{Nd}\right)\left(\mathrm{PbNd}\left(\mathrm{CO}_{3}\right)_{2}(\mathrm{OH}) \cdot \mathrm{H}_{2} \mathrm{O}{ }^{98}\right.$, and all 431 the kozoite isomorphs ${ }^{92}$. The ancylite group is, in fact, a series of complex solid-solutions 432 formed as a consequence of coupled substitutions $\mathrm{REE}^{3+}+\mathrm{OH}^{-}=\mathrm{Me}^{2+}+\mathrm{H}_{2} \mathrm{O}$ (where $\mathrm{Me}^{2+}=$ $\left.433 \mathrm{Ca}^{2+}, \mathrm{Sr}^{2+}, \mathrm{Pb}^{2+}\right)$ and most of the existing structural information about them has been obtained 434 from natural samples (carbonatite deposits, pegmatites of alkaline rocks) ${ }^{92,94}$, and some 435 hydrothermal synthesis experiments $64,66,67$. This large chemical variability of ancylite is 436 translated into variations of unit cell parameters and interatomic distances in their structures, 437 which can promote or inhibit the oriented overgrowth of these phases on calcite. Furthermore, 438 the chemistry of the substrate need also to be considered: our SEM analysis did not detect 439 any Mg (or other elements) in calcite and powder XRD patterns showed that the main Bragg 440 peak of calcite (104) corresponded to a d-spacing of $3.035 \AA$, consistent with a pure (non-Mg441 bearing) calcite ${ }^{99}$. However, it is important to consider that the incorporation of some elements 
442 in the structure of calcite (e.g., $\left.\mathrm{Mg}^{2+}\right)^{100}$ also results in changes to the unit cell dimensions and 443 interatomic distances in this mineral, potentially affecting the described oriented overgrowth.

\section{5. Implications for natural systems}

446 Mineral replacement reactions are common in hydrothermal systems, including carbonatites 447 and other REE-bearing deposits, and they reflect changes in the environmental conditions or 448 fluid composition during the evolution of the system. The crystallisation of REE-bearing 449 carbonates is known to be an efficient process for the immobilisation of REE, and this can 450 happen as a consequence of fluid mixing at hydrothermal conditions, fluid-rock interactions, or 451 changes in PT conditions, among other factors ${ }^{101}$. Our results have sound implications for the 452 understanding of mineralisation reactions occurring in carbonatite deposits.

453 Metasomatic alteration has been identified as a common process taking place in carbonatite 454 deposits ${ }^{30}$, where replacement reactions may have played an important role in the formation 455 or REE-bearing carbonates. Some examples are the Bayan Obo deposit (Mongolia, China), 456 the largest REE resource in the world, which is a metamorphosed and metasomatically altered 457 carbonatite ${ }^{102}$. Also, REE deposits in Vietnam are described as crushed zones in Paleozoic 458 limestone affected by metasomatism ${ }^{103}$. In many of these deposits, REE-carbonates (e.g. 459 ancylite, bastnäsite, monazite) are considered to be of secondary origin as a consequence of 460 mineral replacement at hydrothermal conditions. Armbrustmacher ${ }^{104}$ found carbonate minerals 461 showing textures consistent with pseudomorphic replacements produced by the interaction of 462 hydrothermal fluids with primary minerals in carbonatites from the Wet Mountains Area 463 (Colorado, USA). Moore et al. ${ }^{105}$ found similar results in carbonate deposits in the Bear Lodge 464 carbonatite (Wyoming, USA). However, these deposits are very complex and the REE 465 enrichment mechanism and the genesis of many of REE-carbonate minerals are still under 466 debate due to their complicated mineralogy, element composition and geologic history. 
467 The main REE-bearing minerals associated with carbonatites are fluorocarbonates, like 468 bastnäsite, parisite $\left(\mathrm{Ca}(\mathrm{REE})_{2}\left(\mathrm{CO}_{3}\right)_{3} \mathrm{~F}_{2}\right)$, and synchysite $\left(\mathrm{CaREE}\left(\mathrm{CO}_{3}\right)_{2} \mathrm{~F}\right)$, as well as hydrated 469 carbonates like ancylite $\left(\operatorname{REESr}\left(\mathrm{CO}_{3}\right)_{2}(\mathrm{OH}) \cdot \mathrm{H}_{2} \mathrm{O}\right)$, and phosphates like monazite $(\mathrm{REEPO})_{4}$. 470 These carbonatite deposits are enriched by the four LREE ( $\mathrm{La}, \mathrm{Ce}, \mathrm{Pr}, \mathrm{Nd}$ ). Bastnäsite is the 471 predominant ore mineral, and calcite and dolomite are also present as gangue. Bastnäsite and 472 the other fluorocarbonates in carbonatites are considered to form by four main processes ${ }^{106}$ : 473 (i) Direct high-temperature crystallisation from a carbonatite magma, a mechanism that has 474 been in-depth experimentally studied by Anenburg et al ${ }^{35}$. (ii) Replacement of initially alkali 475 REE carbonates like burbankite $\left((\mathrm{Na}, \mathrm{Ca})_{3}(\mathrm{Sr}, \mathrm{Ba}, \mathrm{REE})_{3}\left(\mathrm{CO}_{3}\right)_{5}\right)$, or carbocernaite $476\left((\mathrm{Ca}, \mathrm{Na})(\mathrm{Sr}, \mathrm{REE}, \mathrm{Ba})\left(\mathrm{CO}_{3}\right)_{2}\right)$ that results in the formation of characteristic textures consisting 477 of fine-grained assemblages of REE fluorocarbonates, monazite, barite and strontianite 478 pseudomorphs ${ }^{35,107,108}$. (iii) Replacement of relatively insoluble REE-bearing minerals during 479 weathering like apatite ${ }^{109}$ or synchysite ${ }^{110}$. (iv) Hydrothermal alteration of calcite, with the REE 480 derived from the calcite itself, to form ${ }^{111}$.

481 Our experiments would be relevant for the understanding of the hydrothermal alteration 482 processes taking place in REE-rich carbonatites (e.g., Okorusu deposit, Nabibia ${ }^{111}$ ). Results 483 demonstrate that REE can be rapidly immobilised even at low hydrothermal conditions as 484 hydroxicarbonates, replacing calcite, and the fluid composition can have strong control of the 485 kinetics, polymorph selection and crystallisation pathways towards bastnäsite during 486 replacement reactions. Hydrogeochemical modelling from high-temperature experimental data 487 has revealed that the main ligands responsible for the transport of the REE at hydrothermal 488 conditions are $\mathrm{Cl}^{-}$and $\mathrm{SO}_{4}{ }^{2-}$ as well as bicarbonate/carbonate ${ }^{38,112}$. Other ligands like $\mathrm{F}^{-}$and $489 \mathrm{OH}^{-}$have been considered to be the main ligands enabling solubility and hydrothermal 490 transport of REE 112,113 . Recently Migdisov et al. ${ }^{38}$ have suggested that $\mathrm{F}^{-}$is in fact, a 491 depositional ligand. Our study suggests that at near-neutral and alkaline conditions, the 492 contribution of the $\mathrm{OH}^{-}$complexes to REE immobilisation could be also significant. 
493 The reactions followed in this study revealed multi-step crystallisation pathways to bastnäsite. 494 The two observed intermediate phases (lanthanite and kozoite) are not abundant in 495 carbonatites. Kozoite has been found in association with an alkali olivine basalt ${ }^{92}$ and also in 496 pegmatite deposits, while lanthanite has been observed in some carbonatites ${ }^{114}$. Although 497 their detection can be complicated if they are present in very low quantities, our data and 498 previous studies ${ }^{85}$ suggest that they may form at hydrothermal conditions and rapidly 499 transform to bastnäsite. Furthemore, the presence of $\mathrm{F}^{-}$and $\mathrm{Sr}^{2+}$ ions would promote the 500 formation of the more stable fluorcarbonates and the crystallisation of ancylite.

501

502

\section{Conclusions}

503 Pseudomorphic mineral replacement of calcite by REE carbonates ( $\mathrm{La}, \mathrm{Nd}, \mathrm{Dy}$ ) takes place at 504 low hydrothermal conditions $\left(50-220^{\circ} \mathrm{C}\right)$ and is strongly controlled by structural constraints 505 which in turn depend on the ionic radius of the involved REE. Calcite grains are replaced from 506 their periphery inwards and the newly formed REE-bearing carbonates follow the crystallisation 507 sequence lanthanite $\left[\mathrm{REE}_{2}\left(\mathrm{CO}_{3}\right)_{3} \cdot 8 \mathrm{H}_{2} \mathrm{O}\right] \rightarrow$ kozoite [orthorhombic REECO $\left.3(\mathrm{OH})\right] \rightarrow$ 508 hydroxylbastnäsite [hexagonal $\mathrm{REECO}_{3}(\mathrm{OH})$ ]. In La- and Nd-rich fluids this solvent-mediated 509 transformation is initiated with the crystallisation of La- and Nd-Kozoite forming an epitaxial 510 overgrowth on the surface of calcite (104) face due to their structural similarities. Temperature 511 and the fluid chemistry (i.e., REE element present in the aqueous solution) control the kinetics 512 of the replacement reaction. These replacement processes are relevant for the understanding 513 of mineralisation reactions occurring in REE-bearing carbonatite deposits and demonstrate 514 that REE can be rapidly immobilised as REE hydroxicarbonates even at low hydrothermal 515 conditions, replacing calcite. Besides, our method allows the synthesis of REE carbonates with 516 tailored structures and chemistries for the production of new innovative materials. 


\section{7. Acknowledgements}

519 This study has been supported by a research grant from the Trinity College Dublin Provost 520 PhD Awards. These doctoral awards are generously funded through alumni donations and 521 Trinity's Commercial Revenue Unit. JDRB would like to acknowledge that this publication has 522 emanated from research supported in part by a research grant from Science Foundation 523 Ireland, Geological Survey of Ireland and the Environmental Protection Agency under the SFI 524 Frontiers for the Future Programme 19/FFP/6535 (project number 210281, award number 525 16370). A.E. would like to thank for the support of the European Union's Horizon 2020 research 526 and innovation programme, Metallntelligence project, under the auspice of Marie Sklodowska527 Curie grant agreement No 722677. The help of the Colin Reid, Leona O'Connor and Paul 528 Guyett from the Centre for Microscopy and Analysis (CMA) and Dr Robbie Goodhue in Unit 7, 529 Trinity Technology and Enterprise Centre (TTEC) is sincerely acknowledged. All authors are 530 grateful for the insightful comments and suggestions given by Dr. Michael Anenburg and an 531 anonymous reviewer. 
533

\section{References}

534 (1) Balaram, V. Rare earth elements: A review of applications, occurrence, exploration, 535 analysis, recycling, and environmental impact. Geosci. Front. 2019, 10, 1285-1303.

536 (2) Haxel, G. B.; Hedrick, J. B.; Orris, G. J. Rare Earth Element Resources: A Basis for High 537 Technology; Fact Sheet 087-02, U. S. Department of Interior, U. S. Geological Survey, $538 \quad$ November, 2002.

539 (3) Zhou, B.; Li, Z.; Chen, C. Global Potential of Rare Earth Resources and Rare Earth Demand 540 from Clean Technologies Minerals 2017, 7, 203.

541 (4) van Gosen, B.S.; Verplanck, P.L.; Long, K.R.; Gambogi, J.; Seal II, R.R. The rare-earth 542 elements: Vital to modern technologies and lifestyles; Fact Sheet 2014-3078, USGS Mineral 543 Resources Program, U. S. Department of Interior, U. S. Geological Survey, Reston, VA, $544 \quad$ November 2014.

545 (5) Kim, P.; Anderko, A.; Navrotsky, A.; Riman, R. Trends in Structure and Thermodynamic 546 Properties of Normal Rare Earth Carbonates and Rare Earth Hydroxycarbonates. Minerals $547 \quad 2018,8,106$.

548 (6) Chakhmouradian, A. R.; Wall, F. Rare Earth Elements: Minerals, Mines, Magnets (and 549 More) Elements 2012, 8, 333-340.

550 (7) Sovacool, B.K.; Ali, S.H.; Bazilian, M.; Radley, B.; Nemery, B.; Okatz, J.; Mulvaney, D. 551 Sustainable minerals and metals for a low-carbon future. Science 2020, 367, 30-33.

552 (8) Teubler, J.; Kiefer, S.; Liedtke, C. Metals for Fuels? The Raw Material Shift by Energy553 Efficient Transport Systems in Europe. Resources 2018, 7, 39. 
554 (9) Goodenough, K.M.; Wall, F.; Merriman, D. The rare Earth elements: Demand, global 555 resources, and challenges for resourcing future generations. Nat. Resour. Res. 2018, 27, 201556216.

557 (10) Wall, F.; Rollat, A.; Pell, R.S. Responsible sourcing of critical metals. Elements 2017, 13, $558 \quad 313-318$.

559 (11) Nassar, N.T.; Du, X.;Graedel, T.E. Criticality of the rare earth elements. J. Ind. Ecol. 2015, $560 \quad 19,1044-1054$.

561 (12) Goonan, T.G. Rare Earth Elements - End Use and Recyclability; U. S. Department of 562 Interior, U.S. Geological Survey, Scientific Investigations Report 2011-5094, Reston, Virginia, 5632011.

564 (13) New Circular Vision for Electronics - Time for a Global Reboot. International 565 Telecommunication Union, Platform for Accelerating the Circular Economy; World Economic 566 Forum; January 2019.

567 (14) FACT SHEET: MANAGEMENT OF ELECTRONIC WASTE IN THE UNITED STATES 568 2008; National Service Center for Environmental Publications (NSCEP), U.S. Environmental 569 Protection $\quad$ Agency. [online] 2007, EPA530-F-08-014. 570 https://nepis.epa.gov/Exe/ZyPURL.cgi?Dockey=P1000ZT5.txt (accessed Nov 27, 2020).

571 (15) Menéndez, I.; Campeny, M.; Quevedo-González, L.; Mangas, J.; Llovet, X.; Tauler, E.; 572 Barrón, V.; Torrent, J.; Méndez-Ramos, J. Distribution of REE-bearing minerals in felsic 573 magmatic rocks and paleosols from Gran Canaria, Spain: Intraplate oceanic islands as a new 574 example of potential, non-conventional sources of rare-earth elements. J. Geochem. Explor. $5752019,204,270-288$. 
576 (16) Palaparthi, J.; Chakrabarti, R.; Banerjee, S.; Guin, R.; Ghosal, S.; Agrahari, S.; Sengupta, 577 D. Economically viable rare earth element eeposits along beach placers of Andhra Pradesh, 578 eastern coast of India. Arab. J. Geosci. 2017, 10, 201.

579 (17) Scott, C.; Kolker, A. Rare earth elements in coal and coal fly ash; Fact Sheet 2019-3048, 580 U. S. Department of Interior, U. S. Geological Survey, September 2019.

581 (18) Emsbo, P.; McLaughlin, P. I., Breit, G. N.; du Bray, E. A.; Koenig, A. E. Rare earth 582 elements in sedimentary phosphate deposits: Solution to the global REE crisis? Gondwana 583 Res. 2015, 27, 776-785.

584 (19) Broom-Fendley, S.; Brady, A. E.; Wall, F.; Gunn, G.; Dawes, W. REE minerals at the 585 Songwe Hill Carbonatite, Malawi: HREE-enrichment in late-stage apatite. Ore Geol. Rev. $5862017,81,23-41$.

587 (20) Croll, R.; Swinden, S.; Hall, M.; Brown, C.; Beer, G.; Scheepers, J.; Redellinghuys, T.; 588 Wild, G.; Trusler, G. Mkango Resources Limited, Songwe REE Project, Malawi; NI 43-101 Pre589 feasibility Report by MSA Group (Pty) Ltd. for Mkango Resources Limited, November 2014.

590 (21) Owens, C. L.; Nash, G. R.; Hadler, K.; Fitzpatrick, R. S.; Anderson, C. G.; Wall, F. Apatite 591 enrichment by rare earth elements: A review of the effects of surface properties. Colloid 592 Interface Sci. 2019, 265, 14-28.

593 (22) Hein, J.R.; Koschinsky, A.; Kuhn, T. Deep-ocean polymetallic nodules as a resource for 594 critical materials. Nat. Rev. Earth Environ. 2020, 1, 158-169.

595 (23) Zhang, Z.; Du, Y.; Gao, L.; Zhang, Y.; Shi, G.; Liu, C.; Zhang, P.; Duan, X. Enrichment of 596 REEs in polymetallic nodules and crusts and its potential for exploitation', J. Rare Earths 2012, $59730,621-626$. 
598 (24) Baturin, G. N.; Yushina, I. G. Rare earth elements in phosphate-ferromanganese crusts 599 on Pacific Seamounts. Lithol. Miner. Resou. 2007, 42, 101-117.

600 (25) Takaya, Y.; Yasukawa, K.; Kawasaki, T.; Fujinaga, K.; Ohta, J.; Usui, Y.; Nakamura, K.; 601 Kimura, J.-I.; Chang, Q.; Hamada, M.; Dodbiba, G.; Nozaki, T.; lijima, K.,;Morisawa, T.; 602 Kuwahara, T.; Ishida, Y.; Ichimura, T.; Kitazume, M.; Fujita, T.; Kato, Y. The tremendous 603 potential of deep-sea mud as a source of rare-earth elements. Sci. Rep. 2018, 8, 5763.

604 (26) McLeod, C.L.; Krekeler, M.P.S. Sources of Extraterrestrial Rare Earth Elements: To the 605 Moon and Beyond. Resources 2017, 6, 40.

606 (27) Mineral and Commodity Summaries: Rare Earths. U. S. Department of Interior, U.S. 607 Geological Survey, Reston, Virginia, 2018.

608 (28) Haque, M.; Hughes, A.; Lim, S.; Vernon, C. Rare earth elements: Overview of mining, 609 mineralogy, uses, sustainability and environmental impact. Resources 2014, 3, 614-635.

610 (29) Leskelä, M.; Niinistö, L. Chapter 56 Inorganic complex compounds. Handbook on the 611 Physics and Chemistry of Rare Earths. Elsevier. 1986; 8, $203-234$.

612 (30) Wall, F. Rare earth elements. Critical Metals Handbook; Gunn G., Eds.; American 613 Geophysical Union. John Wiley \& Sons, Ltd., 2014; pp. 454.

614 (31) Orris, G.; Grauch, R. Rare Earth Element Mines, Deposits, and Occurrences; U. S. 615 Department of Interior, U.S. Geological Survey, Open-File Report 02-189, 2002.

616 (32) Mineral and Commodity Summaries: Rare Earths; U. S. Department of Interior, U.S. 617 Geological Survey, Reston, Virginia, 2019.

618 (33) Amores-Casals, S.; Melgarejo, J.-C.; Bambi, A.; Gonçalves, A.O.; Morais, E.A.; Manuel, 619 J.; Neto, A.B.; Costanzo, A.; Martí Molist, J. Lamprophyre-Carbonatite Magma Mingling and 
620 Subsolidus Processes as Key Controls on Critical Element Concentration in Carbonatites621 The Bonga Complex (Angola). Minerals, 2019, 9, 601.

622 (34) Edahbi, M.; Plante, B.; Benzaazoua, M.; Kormos, L.; Pelletier, M. Rare Earth Elements 623 (La, Ce, Pr, Nd, and Sm) from a Carbonatite Deposit: Mineralogical Characterization and 624 Geochemical Behavior. Minerals 2018, 8, 55.

625 (35) Anenburg, M.; Mavrogenes, J.A.; Frigo, C.; Wall, F. Rare earth element mobility in and 626 around carbonatites controlled by sodium, potassium, and silica. Sci. Adv. 2020, 6, eabb6570.

627 (36) Williams-Jones, A.E.; Migdisov, A.A.; Samson, I.M. Hydrothermal mobilisation of the rare 628 rarth elements - a tale of "Ceria" and "Yttria". Elements 2012, 8, 355-360.

629 (37) Migdisov, A.A.; Williams-Jones, A.E. Hydrothermal transport and deposition of the rare 630 earth elements by fluorine-bearing aqueous liquids. Miner. Depos. 2014, 49, 987-997.

631 (38) Migdisov, A.; Williams-Jones, A.E.; Brugger, J.; Caporuscio, F.A. Hydrothermal transport, 632 deposition, and fractionation of the REE: Experimental data and thermodynamic calculations. 633 Chem. Geol. 2016, 439, 13-42.

634 (39) Migdisov, A.; Guo, X.; Nisbet, H.; Xu, H.; Williams-Jones, A.E. Fractionation of REE, U, 635 and Th in natural ore-forming hydrothermal systems: Thermodynamic modeling. J. Chem. 636 Thermodyn. 2019, 128, 305-319.

637 (40) Lakshtanov, L.Z.; Stipp, S.L.S. Experimental study of europium (III) coprecipitation with 638 calcite.' Geochim. Cosmochim. Acta 2004, 68, 819-827.

639 (41) Gabitov, R.I.; Sadekov, A.; Migdisov, A. REE Incorporation into Calcite Individual Crystals 640 as One Time Spike Addition. Minerals, 2017, 7, 204.

641 (42) Terakado, Y.; Masuda, A. The coprecipitation of rare-earth Elements with calcite and 642 aragonite. Chem. Geol. 1988, 69, 103-110. 
643 (43) Zhong, S., Mucci, A. Partitioning of rare earth elements (REEs) between calcite and 644 seawater solutions at $25{ }^{\circ} \mathrm{C}$ and $1 \mathrm{~atm}$, and high dissolved REE concentrations. Geochim. 645 Cosmochim. Acta 1995, 59, 443-453.

646 (44) Curti, E.; Kulik, D.A.; Tits, J. Solid solutions of trace Eu (III) in calcite: thermodynamic 647 evaluation of experimental data over a wide range of $\mathrm{pH}$ and $\mathrm{pCO}_{2}$. Geochim. Cosmochim. $648 \quad$ Acta. 2005, 69, 1721-1737.

649 (45) Tanaka, K.; Kawabe, I. REE abundances in ancient seawater inferred from marine 650 limestone and experimental REE partition coefficients between calcite and aqueous solution. 651 Geochem. J. 2006, 40, 425-435.

652 (46) Vodyanitskii, Y.N. Geochemical fractionation of lanthanides in soils and rocks: a review of 653 publications. Eurasian Soil Sci. 2012, 45, 56-67.

654 (47) Toyama, K.; Terakado, Y. Experimental study of rare earth element partitioning between 655 calcite and sodium chloride solution at room temperature and pressure. Geochem. J. 2014, $65648,463-477$.

657 (48) Voigt, M.; Mavromatis, V.; Oelkers, E.H. The experimental determination of REE partition 658 coefficients in the water-calcite system. Chem. Geol. 2017, 462, 30-43.

659 (49) Chebotarev, D.A.; Veksler, I.V.; Wohlgemuth-Ueberwasser, C.; Doroshkevich, A.G.; 660 Koch-Müller, M. Experimental study of trace element distribution between calcite, fluorite and 661 carbonatitic melt in the system $\mathrm{CaCO}_{3}+\mathrm{CaF}_{2}+\mathrm{Na}_{2} \mathrm{CO}_{3} \pm \mathrm{Ca}_{3}\left(\mathrm{PO}_{4}\right)_{2}$ at $100 \mathrm{MPa}$. Contrib. 662 Mineral. Petrol. 2019, 174, 4.

663 (50) Möller, P.; De Lucia, M. Incorporation of Rare Earths and Yttrium in Calcite: A Critical Re664 evaluation. Aquat Geochem, 2020, 26, 89-117. 
665 (51) Rodriguez-Blanco, J.D.; Sand, K.K.; Benning, L.G. Chapter 5 ACC and vaterite as 666 metastable intermediates in the solution based crystallization of $\mathrm{CaCO}_{3} . \mathrm{New}$ Perspectives on 667 Mineral Nucleation and Growth. van Driessche, A., Kellermeier, M., Benning, L.G., Gebauer, 668 D., Eds.; Springer International Publishing. Switzerland. 2017.

669 (52) Railsback, L.B. An earth scientist's periodic table of the elements and their ions'. Geology $6702003,31,737-740$.

671 (53) Shannon, R.D. Revised effective ionic radii and systematic studies of interatomic 672 distances in halides and chalcogenides. Acta Crystallogr. A. 1976, 32, 751-767.

673 (54) Weng, Z.; Jowitt, S.M.; Mudd, G.M.; Haque, N. A detailed assessment of global rare earth 674 element resources: opportunities and challenges. Econ. Geol. 2015, 110, 1925-1952.

675 (55) Bauer, D.; Diamond, D.; Li, J.; Sandalow, D.; Telleen, P.; Wanner, B. Technical Report. 676 U.S. Department of Energy Critical Materials Strategy; United States, December 2010.

677 (56) Coelho, A. A. TOPAS Academic: General Profile and Structure Analysis Software for 678 Powder Diffraction Data. 5th ed.; Bruker AXS: Karlsruhe, Germany, 2012.

679 (57) Parkhurst, D. L.; Appelo, C.A.J. Water-Resources Investigations Report Report: 680 PHREEQC(Version 2)-A Computer Program for Speciation, Batch-Reaction, One Dimensional 681 Transport, and Inverse Geochemical Calculations; U. S. Department of Interior, U. S. 682 Geological Survey; Denver, Colorado,1999.

683 (58) Essington, M.E.; Mattigod, S.V. Lanthanide Solid Phase Speciation. Soil Sci. Soc. Am. J. $6841985,49,1387-1393$.

685 (59) Voigt, M.; Rodriguez-Blanco, J.D.; Vallina, B.; Benning, L.G.; Oelkers, E.H. An 686 experimental study of hydroxylbastnasite solubility in aqueous solutions at $25^{\circ} \mathrm{C}$. Chem. Geol. 687 2016, 430, 70-77. 
688 (60) Plummer, L. N.; Busenberg, E. The Solubilities of calcite, aragonite and vaterite in $\mathrm{CO}_{2}$ $689 \mathrm{H}_{2} \mathrm{O}$ solutions between 0 and $90^{\circ} \mathrm{C}$, and an evaluation of the aqueous model for the system $690 \mathrm{CaCO}_{3}-\mathrm{CO}_{2}-\mathrm{H}_{2} \mathrm{O}$. Geochim. Cosmochim. 1982, 46, 1011-1040.

691 (61) Atencio, D.; Bevins, R.; Fleischer, M.; Terry Williams, C.; Williams, P. Revision of the 692 lanthanite group and new data for specimens from Bastnäs, Sweden, and Bethlehem, USA. 693 Mineral. Mag. 1989, 53, 639-642.

694 (62) Rodriguez-Blanco, J. D.; Vallina, B.; Blanco, J. A.; Benning, L. G. The role of REE ${ }^{3+}$ in the 695 crystallization of lanthanites. Mineral. Mag. 2014, 78, 1373-1380.

696 (63) Shinn, D. B.; Eick, H. A. Crystal structure of lanthanum carbonate octahydrate. Inorg. 697 Chem. 1968, 7, 1340-1345.

698 (64) Vallina, B.; Rodriguez-Blanco, J. D.; Brown, A. P.; Blanco, J. A.; Benning, L. G. The role 699 of amorphous precursors in the crystallization of La and Nd carbonates. Nanoscale, 2015, 7, $700 \quad 12166-12179$.

701 (65) Doert, T.; Rademacher, O.;Getzschmann. J. Crystal structure of dysprosium hydroxide 702 carbonate DyOHCO 3 . Z. Kristallogr. NCS. 1999, 214, 11-12.

703 (66) Tahara, T.; Nakai, I.; Miyawaki, R.; Matsubara, S. Crystal chemistry of RE( $\left.\mathrm{CO}_{3}\right) \mathrm{OH}$. Z. 704 Kristallogr. Cryst. Mater. 2007, 222, 326-334.

705 (67) Vallina, B.; Rodriguez-Blanco, J. D.; Brown, A. P.; Blanco, J. A.; Benning, L. G. 706 Amorphous dysprosium carbonate: Characterization, stability, and crystallization pathways. J. 707 Nanopart. Res. 2013, 15, 1438.

708 (68) Hsu, L.C. Synthesis and stability of bastnaesites in a part of the system (Ce,La)-F-H-C709 O.' Mineral. Petrol. 1992, 47, 87-101. 
710 (69) Michiba, K.; Tahara, T.; Nakai, I.; Miyawaki, R.; Matsubara, S. Crystal structure of 711 hexagonal RE( $\left(\mathrm{CO}_{3}\right) \mathrm{OH}$. Z. Kristallogr. Cryst. Mater. 2011, 226, 518-530.

712 (70) Michiba, K.; Miyawaki, R.; Minakawa, T.; Terada, Y.; Nakai, I.; Matsubara, S. Crystal 713 structure of hydroxylbastnäsite-(Ce) from Kamihouri, Miyazaki Prefecture, Japan,' J. Mineral. 714 Petrol. Sci. 2013, 108, 326-334.

715 (71) Williams-Jones, A. E.; Wood, S. A. A preliminary petrogenetic grid for REE 716 fluorocarbonates and associated minerals. Geochim. Cosmochim.Acta 1992, 56, 725-738.

717 (72) Meldrum, F.C.; Cölfen, H. Controlling Mineral Morphologies and Structures in Biological 718 and Synthetic Systems. Chem. Rev. 2008, 108, 4332.

719 (73) Ostwald, W. Zeitschrift fuer Physikalische Chemie. Z. Phys. Chem. 1897, 22, 289-330.

720 (74) Bots, P.; Benning, L.G.; Rodriguez-Blanco, J.D.; Roncal-Herrero, T.; Shaw, S. 721 Mechanistic insights into the crystallization of amorphous calcium carbonate to vaterite. Cryst. 722 Growth Des. 2012, 12, 3806-3814.

723 (75) Van Driessche, A.E.S.; Benning, L.G.; Rodriguez-Blanco, J.D.; Ossorio, M.; Bots, P.; 724 García-Ruiz, J.M. The Role and Implications of Bassanite as a Stable Precursor Phase to 725 Gypsum Precipitation. Science, 2012, 336, 69-72.

726 (76) Firsching, F.H.; Mohammadzadei, J. Solubility products of the rare-earth carbonates. J. 727 Chem. Eng. Data 1986, 31, 40-42.

728 (77) Ciavatta, L;, Ferri, D.; Grenthe, I.; Salvatore, F.; Spahiu, K. Studies on Metal Carbonate 729 Equilibria. 3. The Lanthanum(III) Carbonate Complexes in Aqueous Perchlorate Media. Acta 730 Chem. Scand. 1981, 35a, 403-413. 
731 (78) Anderson, J.G.; Doraiswamy, L.K.; Larson, M.A. Microphase-assisted 'autocatalysis' in a 732 solid-liquid reaction with a precipitating product - I. Theory. Chem. Eng. Sci. 1998, 53, 24517332458.

734 (79) Anderson, J.G.; Larson, M.A.; Doraiswamy, L.K. Microphase-assisted "autocatalysis" in a 735 solid-liquid reaction with a precipitating product - II. Experimental. Chem. Eng. Sci. 1998, 53, $736 \quad 2459-2468$.

737 (80) Van Der Merwe, J.H. The role of lattice misfit in epitaxy. Crit. Rev. Solid State Mater. Sci. 738 1978, 7, 209-231.

739 (81) Walton, A. G. Nucleation in Liquids and Solutions. Nucleation; Zettlemoyer, A. C., Eds.; 740 Dekker: NewYork, 1969; pp. 225-307.

741 (82) Cartledge, G.H. Studies on the periodic system. I. The ionic potential as a periodic 742 function', J. Am. Chem. Soc. 1928, 50, 2855-2863.

743 (83) Cartledge, G.H. Studies on the periodic system. li. The ionic potential and related 744 properties. J. Am. Chem. Soc. 1928, 50, 2863-2872.

745 (84) Rodriguez-Blanco, J.D.; Shaw, S.; Bots P.; Roncal-Herrero, T.; Benning, L.G. The role of $746 \mathrm{Mg}$ in the crystallisation of monohydrocalcite. Geochim. Cosmochim. Acta 2014, 127, 204-220.

747 (85) Rodriguez-Blanco, J.D.; Shaw, S.; Benning, L.G. A route for the direct crystallization of 748 dolomite. Am. Mineral. 2015, 100, 1172-1181.

749 (86) Vallina, B.; Rodriguez-Blanco, J. D.; Blanco, J. A.; Benning, L. G. The effect of heating on 750 the morphology of crystalline neodymium hydroxycarbonate, $\mathrm{NdCO}_{3} \mathrm{OH}$. Mineral. Mag. 2014, $75178,1391-1397$. 
752 (87) Sand, K.K.; Rodriguez-Blanco, J.D.; Makovicky, E.; Benning, L.G.; Stipp, S. Crystallization 753 of $\mathrm{CaCO}_{3}$ in water-ethanol mixtures: spherulitic growth, polymorph stabilization and 754 morphology change. Cryst. Growth Des. 2012, 12, 842-853.

755 (88) Gránásy, L.; Pusztai, T.; Tegze, G.; Warren, J.A.; Douglas, J.F. Growth and form of 756 spherulites. Phys. Rev. E. Stat. Nonlin. Soft Matter. Phys. 2005, 72, 011605.

757 (89) Beck, R.; Andreassen, J.P. Spherulitic Growth of Calcium Carbonate. Cryst. Growth Des. $758 \quad 2010,10,2934-2947$.

759 (90) Andreassen, J.P.; Flaten, E.; Beck, R.; Lewis, A.E. Investigations of spherulitic growth in 760 industrial crystallization. Chem. Eng. Res. Des. 2010, 88, 1163-1168.

761 (91) Shtukenberg, A.G.; Punin, Y.O.; Gunn E.; Kahr B. Spherulites. Chem. Rev. 2012, 112, $762 \quad 1805-1838$.

763 (92) Miyawaki, R.; Matsubara, S.; Yokoyama, K.; Takeuchi, K.; Terada, Y.; Nakai, I. Kozoite$764(\mathrm{Nd}), \mathrm{Nd}(\mathrm{CO})(\mathrm{OH})$, a new mineral in an alkali olivine basalt from Hizen-cho, Saga Prefecture, 765 Japan. Am. Mineral. 2000, 85, 1076-1081.

766 (93) Belovitskaya, Y.V.; Pekov, I.V.; Gobechiya, E.R.; Yamnova, N.A.; Kabalov, Y.K.; 767 Chukanov, N.V.; Schneider, J. Crystal structures of two ancylite modifications. Crystallogr. 768 Rep. 2002, 47, 223-228.

769 (94) Dal Negro, A.; Rossi, G.; Tazzoli, V. The crystal structure of ancylite, $(\mathrm{RE})_{\mathrm{x}},(\mathrm{Ca}, \mathrm{Sr})_{2-}$ $770 \times\left(\mathrm{CO}_{3}\right)_{2}(\mathrm{OH})_{\times}(2-\mathrm{x}) \mathrm{H}_{2} \mathrm{O}$. Am. MIneral. 1975, 60, 280-284.

771 (95) Yakovenchuk, V.N.; Men'shikov, Y.P.; Pakhomovskii, Y.A.; Ivanyuk G.Y. Ancylite-(La), $772 \mathrm{Sr}(\mathrm{La}, \mathrm{Ce})(\mathrm{CO} 3) 2(\mathrm{OH}) \bullet \mathrm{H} 2 \mathrm{O}$ - a new carbonate from a hydrothermal vein at Kukisvumchorr 773 Mountain (Khibiny massif) and its comparison with ancylite-(Ce). Zap. Vses. Mineral. Obshch. 774 1997, 126, 96-108. 
775 (96) Larsen, A.O.; Gault, RA. Calcio-ancylite-(Ce) from syenite pegmatite at Tvedalen, Oslo 776 Region, Norway', Neues Jahrb. für Mineral. Monatshefte 2002, 9, 411-423.

777 (97) Orlandi, P.; Pasero, M.; Vezzalini, G. Calcio-ancylite-(Nd), a new REE-carbonate from 778 Baveno, Italy', Eur. J. Mineral. 1990, 2, 413-418.

779 (98) Sarp, H.; Bertrand, J. Gysinite, $\mathrm{Pb}(\mathrm{Nd}, \mathrm{La})(\mathrm{CO} 3) 2(\mathrm{OH}) \cdot \mathrm{H} 2 \mathrm{O}$, a new lead, rare-earth 780 carbonate from Shinkolobwe, Shaba, Zaïre and its relationship to ancylite. Am. Mineral. 1985, $78170,1314-1317$.

782 (99) Arvidson, R.S.; Mackenzie, F.T. The dolomite problem: Control of precipitation kinetics by 783 temperature and saturation state. Am. J. Sci. 1999, 299, 257-288.

784 (100) Paquette, J.; Reeder, R.J. Single-crystal X-ray structure refinements of two biogenic 785 magnesian calcite crystals. Am. Mineral., 1990, 75, 1151-1158.

786 (101) Jones, A.P.; Wall, F.; Williams, C.T. Formation of Rare Earth Minerals in Hydrothermal 787 Systems. In Rare Earth Minerals: Chemistry, Origin and Ore Deposits; The Mineralogical 788 Society Series: Springer Netherlands, 1996.

789 (102) Chao, E.C.T.; Back, J.M.; Minkin, J.A.; Yinchen, R. Host-rock controlled epigenetic, 790 hydrothermal metasomatic origin of the Bayan Obo REEFe-Nb ore deposit, Inner Mongolia, 791 P.R.C. Appl. Geochemistry 1992, 7, 443-458.

792 (103) Premoli, C. Vietnamese metallic mineral resources. Eng. Min. J. 1989, 190, 31-35.

793 (104) Armbrustmacher, T. J. Replacement and primary magmatic carbonatites from the Wet 794 Mountains area, Fremont and Custer counties, Colorado. Econ. Geol. 1979, 74, 888-901.

795 (105) Moore, M.; Chakhmouradian, A. R.; Mariano, A. N.; Sidhu, R. Evolution of rare-earth 796 mineralization in the Bear Lodge carbonatite, Wyoming: Mineralogical and isotopic evidence. 797 Ore Geol. Rev. 2015, 60, 499-521. 
798 (106) Verplanck, P.L.; Mariano, A.N.; Mariano Jr., A. Rare earth element ore geology of 799 carbonatites. In Rare Earth and Critical Elements in Ore Deposits; Verplanck, P.L., Hitzman, 800 M.W., Eds.; Society of Economic Geologists, Littleton, Colorado, USA. 2016; Vol. 18, pp 580132.

802 (107) Andersen, A.K.; Clark, J.G.; Larson, P.B.; Donovan, J.J. REE fractionation, mineral 803 speciation, and supergene enrichment of the Bear Lodge carbonatites, Wyoming, USA. Ore 804 Geol. Rev. 2017, 89, 780-807.

805 (108) Kozlov, E.; Fomina, E.; Sidorov, M.; Shilovskikh, V.; Bocharov, V.; Chernyavsky, A.; 806 Huber, M. The Petyayan-Vara carbonatite-hosted rare earth deposit (Vuoriyarvi, NW Russia): 807 mineralogy and geochemistry. Minerals 2020, 10, 73.

808 (109) Anenburg, M.; Burnham, A.D.; Mavrogenes, J.A. REE redistribution textures in altered 809 fluorapatite: Symplectites, veins and phosphate-silicate-carbonate assemblages from the 810 Nolans Bore P-REE-Th deposit, NT, Australia. Can. Mineral. 2018, 56, 331-354.

811 (110) Witt, W.K.. Hammond, D.P.; Hughes, M. Geology of the Ngualla carbonatite complex, 812 Tanzania, and origin of the Weathered Bastnaesite Zone REE ore. Ore Geol. Rev. 2019, 105, $813 \quad 28-54$.

814 (111) Cangelosi, D.; Broom-Fendley, S.; Banks, D.; Morgan, D.; Yardley, B. Light rare earth 815 element redistribution during hydrothermal alteration at the Okorusu carbonatite complex, 816 Namibia. Mineral. Mag. 2020, 84, 49-64.

817 (112) Perry, E.P.; Gysi, A.P. Rare Earth Elements in Mineral Deposits: Speciation 818 inHydrothermal Fluids and Partitioning in Calcite. Geofluids 2018, 1-19.

819 (113) Banks, D.; Yardley, B.; Campbell, A.; Jarvis, K. REE composition of an aqueous 820 magmatic fluid: a fluid inclusion study from the Capitan Pluton, New Mexico, U.S.A. Chem. 821 Geol. 1994, 113, 259-272. 
822 (114) Zaitsev, A.N.; Wall, F.; Le Bas, M.J. REE-Sr-Ba minerals from the Khibina carbonatites, 823 Kola Peninsula, Russia: their mineralogy, paragenesis and evolution. Mineral. Mag. 1998, 62, $824 \quad 225-250$.

825

826

827

\section{Figure Captions}

828

829

Figure 1: Powder XRD patterns of La-lanthanite with calcite, La-kozoite and La830 hydroxylbastnäsite obtained as final products of the experiments carried out at 21, 50 and 220 831 ${ }^{\circ} \mathrm{C}$, respectively.

832 Figure 2: Powder XRD patterns of Nd-lanthanite with calcite, Nd-kozoite and $\mathrm{Nd}$ 833 hydroxylbastnäsite, obtained as final products of the experiments carried out at 21, 50 and 220 $834{ }^{\circ} \mathrm{C}$, respectively.

835 Figure 3: Powder XRD pattern of Dy-kozoite obtained as the final product of the experiment 836 carried out at $95^{\circ} \mathrm{C}$.

837 Figure 4: Powder XRD patterns showing the full replacement of calcite by Nd-kozoite at 50 838 ${ }^{\circ} \mathrm{C}$. (a) 0 days, (b) 0.75 days $\mathrm{h}$, (c) 1.75 days, and (d) 11 days.

839 Figure 5.: SEM micrographs of the surface of calcite grains exposed to La-bearing solutions 840 at $95{ }^{\circ} \mathrm{C}$. (a) After 0.75 days of reaction, some crystals of La-kozoite are scattered on the 841 surface of calcite. (b) La-kozoite crystals quickly cover the available surface after 1.75 days. 842 (c) The full calcite grain is replaced by La-kozoite after 13 days. 
843 Figure 6.: SEM micrographs showing: (a) The surface of calcite completely covered by La844 lanthanite after 42 days of reaction at $21^{\circ} \mathrm{C}$ (b). Detail of La-lanthanite crystal aggregates. (c) 845 Scattered crystals of Nd-lanthanite on the surface of calcite after 145 days of reaction at 21 $846 \quad{ }^{\circ} \mathrm{C} .(\mathrm{d})$ Morphology of Nd-lanthanite single crystals.

847 Figure 7: SEM micrographs of (a) newly-formed La-kozoite with random orientation of the 848 surface of calcite; (b) La-kozoite with some individual crystals oriented on calcite; (c) $\mathrm{Nd}$ 849 kozoite oriented on the (104) surface of calcite; (d) detail of single crystals of Nd-kozoite 850 oriented on the (104) surface calcite; (e) Dy-kozoite overgrowth on calcite (f) Dy-kozoite with 851 prismatic shapes crystallised on surface of calcite at $220^{\circ} \mathrm{C}$. Figure 8: SEM images of (a) newly-formed La-hydroxylbastnäsite and (b) Nd853 hydroxylbastnäsite replacing calcite formed at $220^{\circ} \mathrm{C}$.

854 Figure 9: SEM micrographs showing oriented Nd-kozoite grown onto the (104) surface of 855 calcite. (a) Overall view of a calcite grain showing the early stages of development of $\mathrm{Nd}$ 856 kozoite; (b) detail of the calcite surface showing Nd-kozoite crystals attached to the calcite 857 surface. (d) Calcite surface completely covered by Nd-kozoite crystals.

858 Figure 10: Schematic diagram showing the epitaxial relationship between kozoite and calcite 859 crystals.

860 Figure 11: Reaction pathways towards bastnäsite observed during the replacement of calcite 861 by rare earth carbonates. Continuous lines correspond to observed reactions, while dashed 862 lines correspond to expected reactions that were not observed in our experiments. Each line 863 shows the temperature at which the reaction takes place.

864 Figure 12: Projection of the crystal structures of a (104) slice of calcite and a (001) slice of 865 kozoite showing the main directions of epitaxy and the repeating periods. 
868 Table 1. Experimental conditions with identities and morphologies of the solid rare earth carbonate phases formed during the interaction of calcite 869 with rare earth bearing aqueous solutions. Abbreviations Lan, Koz and HB, stand for lanthanite, kozoite and hydroxylbastnäsite, respectively.

\begin{tabular}{|c|c|c|c|c|c|c|c|c|c|c|}
\hline & & \multicolumn{3}{|c|}{ La system Molar ratio $\mathrm{Ca} / \mathrm{La} \sim 1$} & \multicolumn{3}{|c|}{ Nd system Molar ratio $\mathrm{Ca} / \mathrm{Nd} \sim 1$} & \multicolumn{3}{|c|}{ Dy system Molar ratio $\mathrm{Ca} / \mathrm{Dy} \sim 1$} \\
\hline $\begin{array}{c}\mathrm{T} \\
\left({ }^{\circ} \mathrm{C}\right)\end{array}$ & $\begin{array}{c}\text { Time } \\
\text { (days) }\end{array}$ & $\begin{array}{c}\% \text { calcite } \\
\text { consumed }\end{array}$ & $\begin{array}{c}\text { Phase } \\
\text { formed }\end{array}$ & Morphology & $\begin{array}{l}\% \text { calcite } \\
\text { consumed }\end{array}$ & $\begin{array}{l}\text { Phase } \\
\text { formed }\end{array}$ & Morphology & $\begin{array}{l}\% \text { calcite } \\
\text { consumed }\end{array}$ & $\begin{array}{l}\text { Phase } \\
\text { formed }\end{array}$ & Morphology \\
\hline \multirow{5}{*}{21} & 7 & 0 & -- & -- & \multirow{4}{*}{0} & \multirow{4}{*}{-- } & \multirow{4}{*}{--} & \multirow{4}{*}{0} & \multirow{4}{*}{--} & \multirow{4}{*}{--} \\
\hline & 14 & 6 & \multirow{4}{*}{ Lan } & \multirow{4}{*}{$\begin{array}{l}\text { Thin platy } \\
\text { crystals }\end{array}$} & & & & & & \\
\hline & 21 & 8 & & & & & & & & \\
\hline & 42 & 10 & & & & & & & & \\
\hline & 145 & 15 & & & 2 & Lan & $\begin{array}{l}\text { Thin platy } \\
\text { crystals }\end{array}$ & $<1$ & Koz & $\begin{array}{l}\text { Fibrous } \\
\text { aggregates with } \\
\text { some branching }\end{array}$ \\
\hline
\end{tabular}

\begin{tabular}{|c|c|c|c|c|c|c|c|c|c|c|}
\hline \multirow{7}{*}{50} & 1 & 0 & \multirow[b]{2}{*}{--} & \multirow[b]{2}{*}{--} & 0 & -- & -- & \multirow{4}{*}{0} & \multirow{4}{*}{--} & \multirow{4}{*}{--} \\
\hline & 2 & 0 & & & 8 & \multirow{6}{*}{ Koz } & \multirow{2}{*}{$\begin{array}{l}\text { Spindle, } \\
\text { oriented }\end{array}$} & & & \\
\hline & 5 & 33 & \multirow{5}{*}{ Koz } & Small prisms & 12 & & & & & \\
\hline & 7 & 55 & & & 52 & & & & & \\
\hline & 9 & 89 & & Elongated & 88 & & Spindle, some & 60 & & \\
\hline & 14 & 99 & & $\begin{array}{l}\text { prisms, } \\
\text { sometimes }\end{array}$ & 96 & & oriented, more & 94 & Koz & $\begin{array}{l}\text { Fibrous } \\
\text { agregates with }\end{array}$ \\
\hline & $\frac{20}{28}$ & 100 & & oriented & 100 & & elongated & 100 & $\mathrm{~N} 02$ & some branching \\
\hline
\end{tabular}

\begin{tabular}{|c|c|c|c|c|c|c|c|c|c|c|}
\hline \multirow{8}{*}{95} & 0.25 & 0 & -- & -- & 0 & -- & -- & 0 & -- & -- \\
\hline & 0.75 & 3 & \multirow{6}{*}{ Koz } & \multirow{7}{*}{$\begin{array}{c}\text { Elongated } \\
\text { prisms }\end{array}$} & 2 & \multirow{6}{*}{$\mathrm{Koz}$} & \multirow{7}{*}{$\begin{array}{l}\text { Spindle, some } \\
\text { oriented, more } \\
\text { elongated }\end{array}$} & 1 & \multirow{7}{*}{ Koz } & \multirow{7}{*}{$\begin{array}{c}\text { Fibrous } \\
\text { aggregates with } \\
\text { some branching }\end{array}$} \\
\hline & 1 & 9 & & & 9 & & & 2 & & \\
\hline & 1.5 & 11 & & & 12 & & & 7 & & \\
\hline & 1.75 & 14 & & & 16 & & & 12 & & \\
\hline & 11 & \multirow{3}{*}{100} & & & \multirow{3}{*}{100} & & & \multirow{3}{*}{100} & & \\
\hline & 13 & & & & & & & & & \\
\hline & 154 & & $\begin{array}{c}>98 \% \mathrm{Koz} \\
<2 \% \mathrm{HB}\end{array}$ & & & $\begin{array}{c}>99 \% \mathrm{Koz} \\
<1 \% \mathrm{HB}\end{array}$ & & & & \\
\hline & & & & & & & & & & \\
\hline \multirow{5}{*}{160} & 1 & \multirow{5}{*}{100} & Koz & \multirow{2}{*}{$\begin{array}{l}\text { Elongated } \\
\text { prisms }\end{array}$} & \multirow{5}{*}{100} & \multirow{5}{*}{$\mathrm{Koz}$} & \multirow{5}{*}{$\begin{array}{l}\text { Spindle, some } \\
\text { oriented, more } \\
\text { elongated }\end{array}$} & \multirow{5}{*}{100} & \multirow{5}{*}{ Koz } & \multirow{5}{*}{$\begin{array}{l}\text { Tabular and } \\
\text { prismatic } \\
\text { crystals }\end{array}$} \\
\hline & 2 & & $\mathrm{Koz}$ & & & & & & & \\
\hline & 5 & & $\begin{array}{l}16 \% \text { Koz } \\
84 \% \mathrm{HB}\end{array}$ & \multirow{3}{*}{$\begin{array}{l}\text { Elongated } \\
\text { prisms (Koz) } \\
+ \text { triangular } \\
\text { prisms (HB) }\end{array}$} & & & & & & \\
\hline & 7 & & $\begin{array}{c}20 \% \mathrm{Koz} \\
80 \% \mathrm{HB}\end{array}$ & & & & & & & \\
\hline & 14 & & $20 \% \mathrm{Koz}$ & & & & & & & \\
\hline
\end{tabular}




\begin{tabular}{|c|c|c|c|c|c|c|c|c|c|c|}
\hline & $\begin{array}{l}21 \\
28 \\
\end{array}$ & & $\begin{array}{r}80 \% \mathrm{HB} \\
<1 \% \mathrm{Koz} \\
>99 \% \mathrm{HB} \\
100 \% \mathrm{HB} \\
\end{array}$ & $\begin{array}{l}\text { Triangular } \\
\text { prisms }\end{array}$ & & & & & & \\
\hline \multirow{3}{*}{220} & 1 & \multirow{3}{*}{100} & \multirow{3}{*}{$\mathrm{HB}$} & \multirow{3}{*}{$\begin{array}{l}\text { Triangular } \\
\text { prisms (HB) }\end{array}$} & \multirow{3}{*}{100} & Koz & \multirow{3}{*}{$\begin{array}{c}\text { Spindle, } \\
\text { elongated } \\
\text { (Koz) + } \\
\text { rectangular } \\
\text { prisms (HB) }\end{array}$} & \multirow{3}{*}{100} & \multirow{3}{*}{ Koz } & \multirow{3}{*}{$\begin{array}{c}\text { Tabular and } \\
\text { prismatic } \\
\text { crystals }\end{array}$} \\
\hline & 5 & & & & & $\begin{array}{l}55 \% \mathrm{Koz} \\
45 \% \mathrm{HB} \\
\end{array}$ & & & & \\
\hline & 7 & & & & & $\mathrm{HB}$ & & & & \\
\hline
\end{tabular}


Table 2. Unit cell parameters of original calcite and the La-, $\mathrm{Nd}$ - and Dy-bearing carbonate minerals crystallised in the experiments.

\begin{tabular}{|c|c|c|c|c|}
\hline Mineral & Space group & La-system & Nd-system & Dy-system \\
\hline Calcite & $\begin{array}{c}\mathrm{R} \overline{3} \mathrm{c} \\
\mathrm{a}=\mathrm{b}=4.989 \AA \\
\mathrm{c}=17.062 \AA \\
\mathrm{Vol}=367.78 \AA^{3}\end{array}$ & -10 & onch & 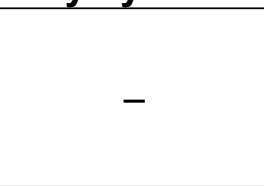 \\
\hline Lanthanite & Pbnb & $\begin{array}{c}\mathrm{a}=8.978(2) \AA \\
\mathrm{b}=9.558(2) \AA \\
\mathrm{c}=17.035(4) \AA \\
\mathrm{Vol}=1461.8 \AA^{3}\end{array}$ & $\begin{array}{c}\mathrm{a}=8.893(2) \AA \\
\mathrm{b}=9.440(3) \AA \\
\mathrm{c}=16.924(5) \AA \\
\mathrm{Vol}=1420.7 \AA^{3}\end{array}$ & - \\
\hline Kozoite & Pmcn & $\begin{array}{l}\mathrm{a}=5.036(2) \AA \\
\mathrm{b}=8.587(3) \AA \\
\mathrm{c}=7.403(2) \AA \\
\mathrm{Vol}=320.1 \AA^{3}\end{array}$ & $\begin{array}{l}a=4.953(1) \AA \\
b=8.482(2) \AA \\
c=7.221(1) \AA \\
\mathrm{Vol}=303.3 \AA^{3}\end{array}$ & $\begin{array}{l}\mathrm{a}=4.839(6) \AA \\
\mathrm{b}=8.444(4) \AA \\
\mathrm{c}=6.984(1) \AA \\
\mathrm{Vol}=285.3 \AA^{3}\end{array}$ \\
\hline hydroxylbastnäsite & $P \overline{6} 2 c$ & $\begin{array}{l}a=12.629(8) \AA \\
c=10.046(3) \AA \\
\mathrm{Vol}=1386.4 \AA^{3}\end{array}$ & $\begin{array}{c}a=12.336(2) \AA \\
c=9.918(1) \AA \\
V o l=1309.0 \AA^{3}\end{array}$ & - \\
\hline
\end{tabular}




\section{For Table of Contents Use Only}

902 Reaction pathways towards the formation of bastnäsite: replacement of calcite by rare 903 earth carbonates.

904 Adrienn Maria Szucs ${ }^{1,}{ }^{2}$, Alexandra Stavropoulou ${ }^{1}$, Claire O'Donnell ${ }^{1}$, Seana Davis ${ }^{1}$, Juan 905 Diego Rodriguez-Blanco 1,3

$9061_{\mathrm{i} C R A G}$, Department of Geology, School of Natural Sciences, Trinity College Dublin, Ireland. 907 2szcsa@tcd.ie; 3J.D.Rodriguez-Blanco@tcd.ie

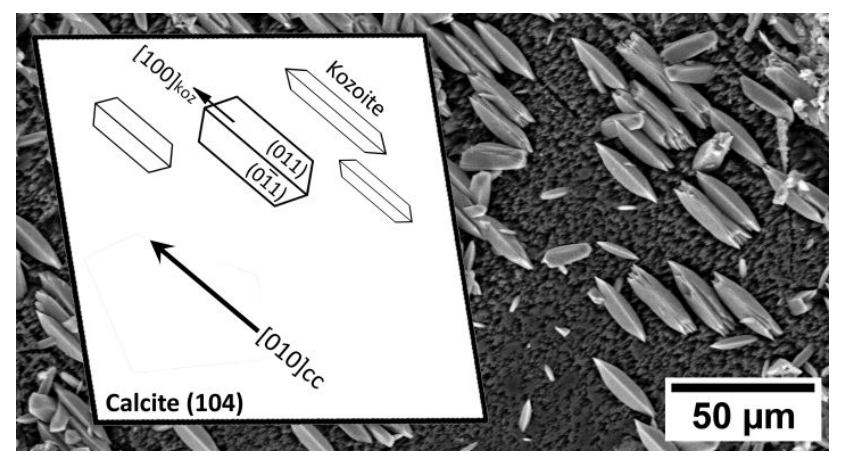

909 Synopsis

910 The interaction of rare earth bearing ( $\mathrm{La}, \mathrm{Nd}$, Dy) fluids with calcite at ambient and 911 hydrothermal conditions $\left(25-220^{\circ} \mathrm{C}\right)$ results in the solvent-mediated surface precipitation and 912 subsequent pseudomorphic mineral replacement of calcite by rare earth carbonates, following 913 the crystallisation sequence lanthanite $\left[\mathrm{REE}_{2}\left(\mathrm{CO}_{3}\right)_{3} \cdot 8 \mathrm{H}_{2} \mathrm{O}\right] \rightarrow$ kozoite [orthorhombic $\left.914 \mathrm{REECO}_{3}(\mathrm{OH})\right] \rightarrow$ hydroxylbastnäsite [hexagonal $\operatorname{REECO}_{3}(\mathrm{OH})$ ]. Kozoite grows oriented onto 915 the calcite surface, forming an epitaxy. 


\section{Description of Supporting Information}

918 Supporting information includes (1) opitical images of calcite crystals after reaction with a $\mathrm{Nd}$ 919 bearing solution, and (2) Ca content (atomic\%) in REE-bearing carbonates determined with 920 energy dispersive spectroscopy (EDS) analysis using scanning electron microscopy (SEM) . 921 


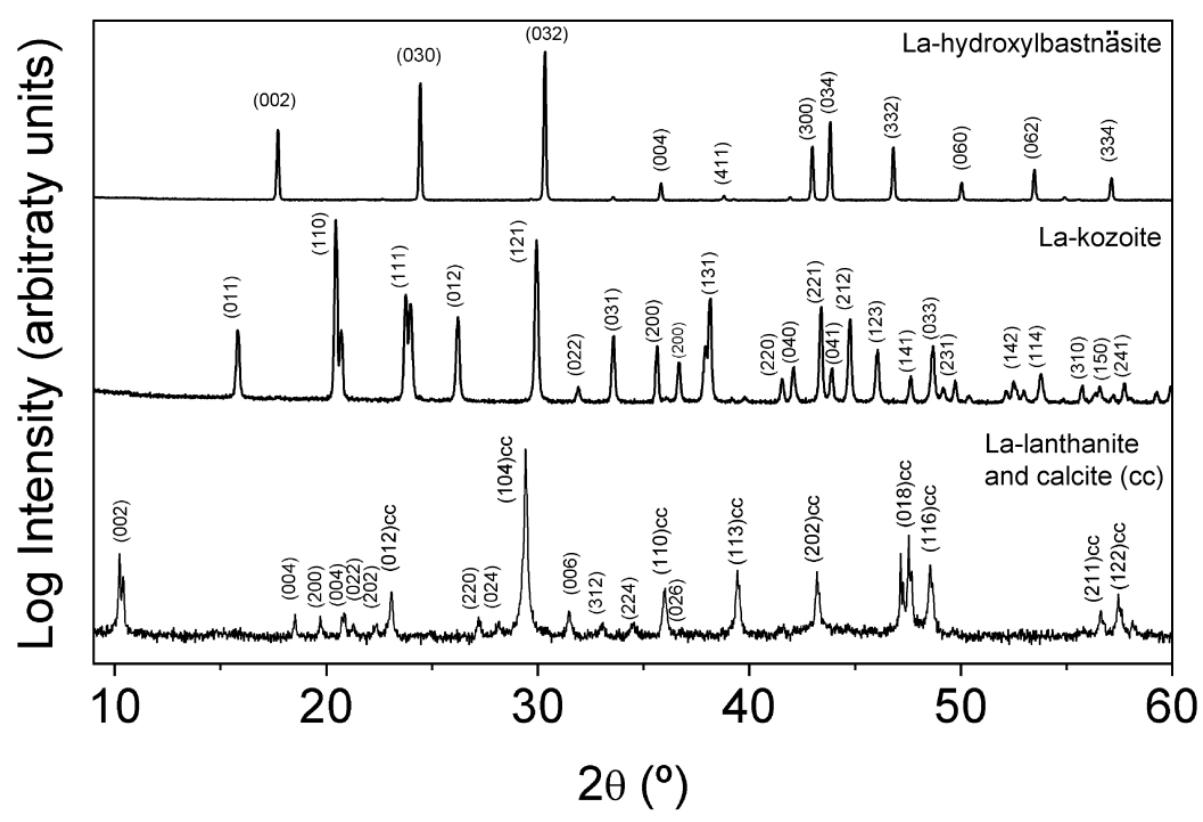

Figure 1: Powder XRD patterns of La-lanthanite with calcite, La-kozoite and La- hydroxylbastnäsite obtained as final products of the experiments carried out at 21,50 and $220^{\circ} \mathrm{C}$, respectively.

$84 \times 56 \mathrm{~mm}(1200 \times 1200 \mathrm{DPI})$ 


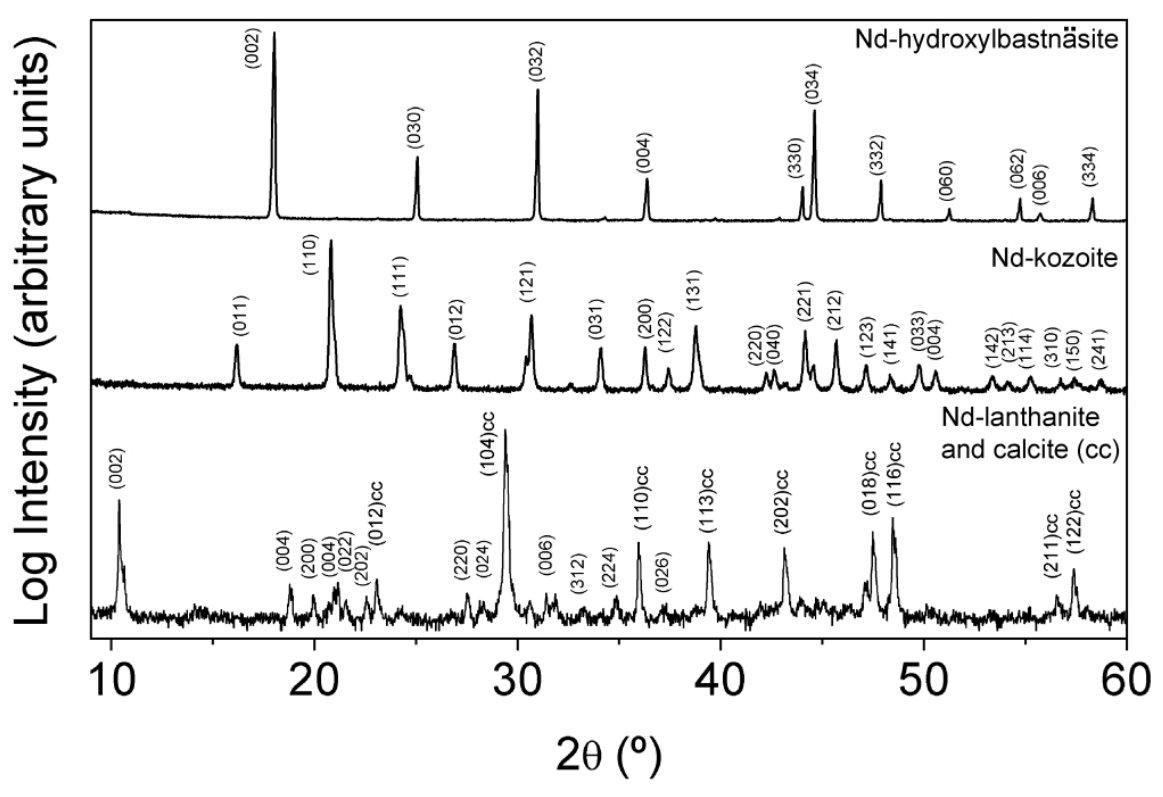

Figure 2: Powder XRD patterns of Nd-lanthanite with calcite, Nd-kozoite and Nd-hydroxylbastnäsite, obtained as final products of the experiments carried out at 21,50 and $220^{\circ} \mathrm{C}$, respectively.

$84 \times 52 \mathrm{~mm}(1200 \times 1200$ DPI $)$ 


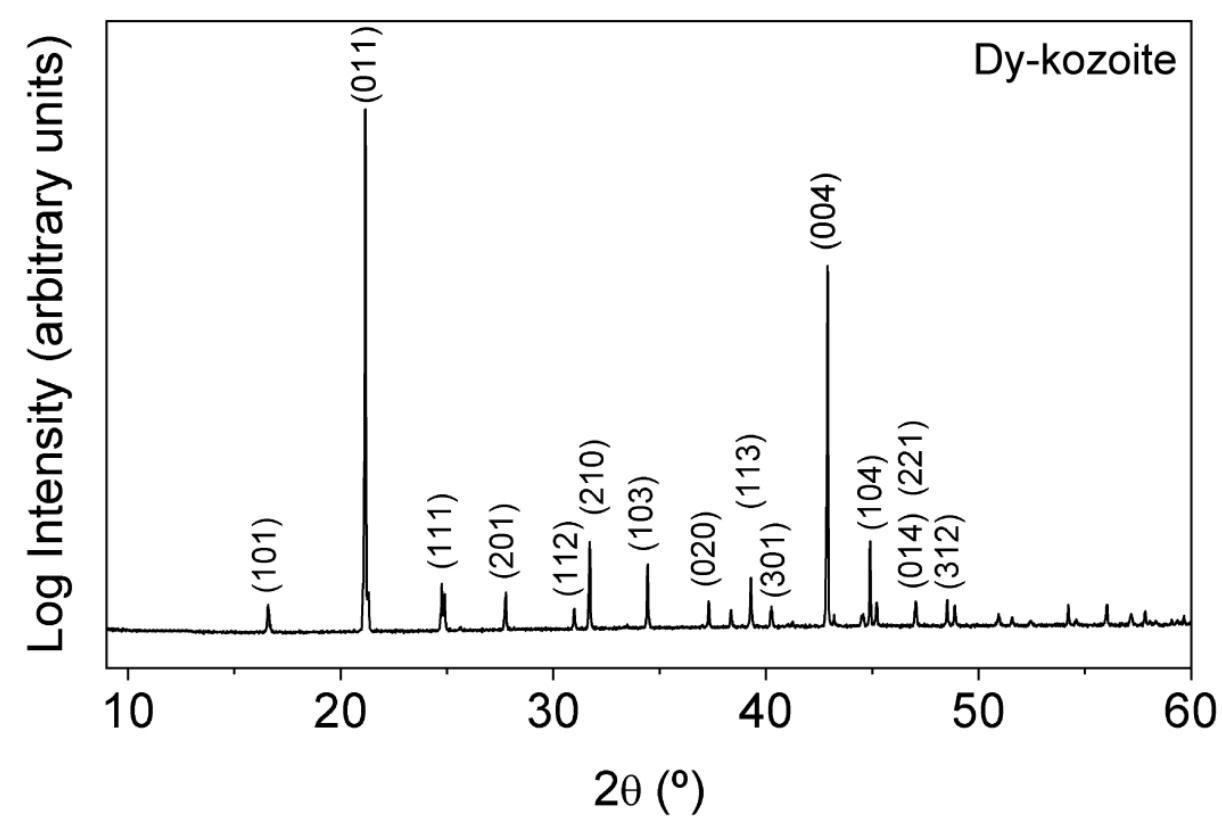

Figure 3: Powder XRD pattern of Dy-kozoite obtained as the final product of the experiment carried out at $95^{\circ} \mathrm{C}$.

$84 \times 56 \mathrm{~mm}(1200 \times 1200$ DPI $)$ 


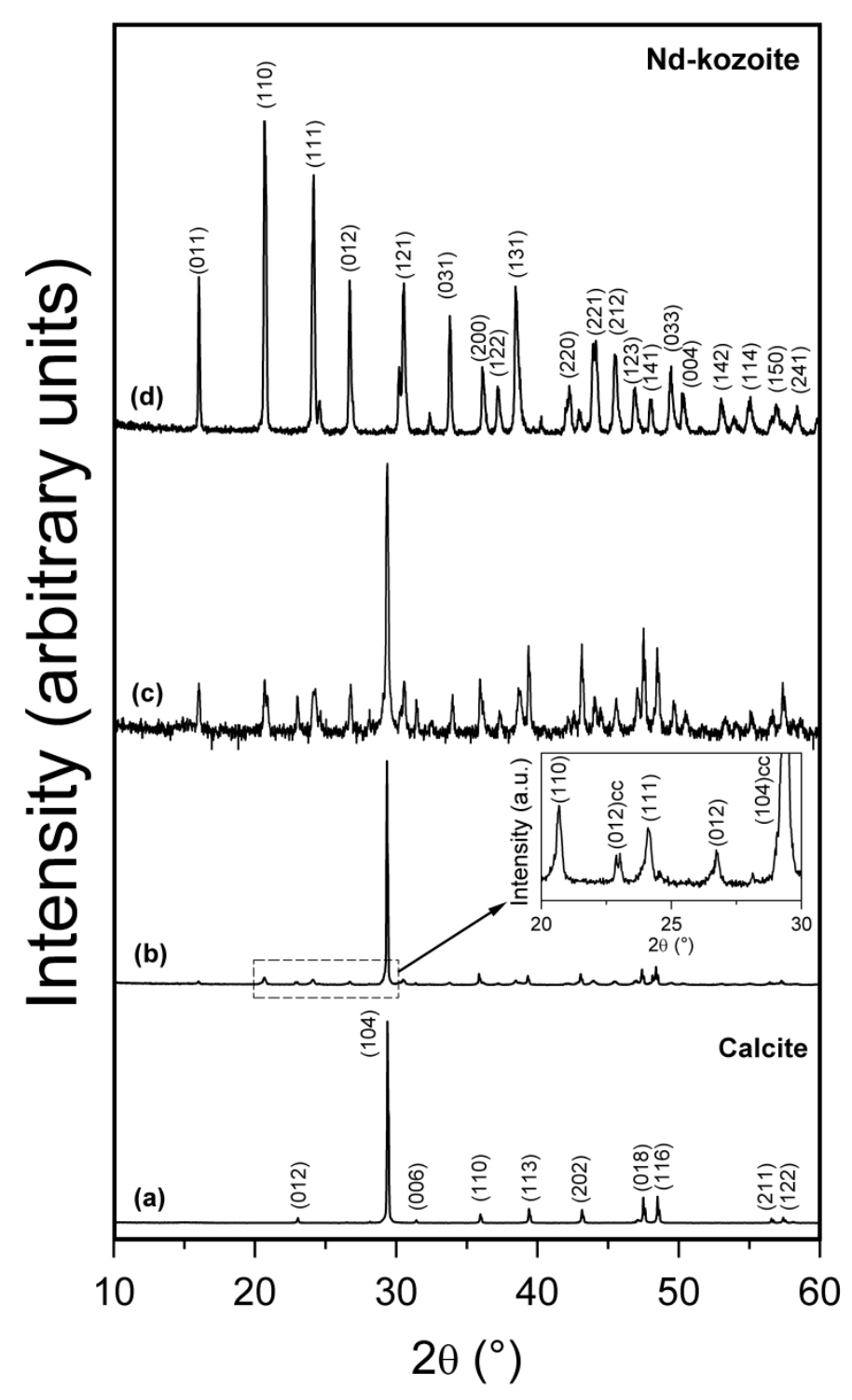

Figure 4: Powder XRD patterns showing the full replacement of calcite by Nd-kozoite at $50{ }^{\circ} \mathrm{C}$. (a) 0 days, (b) 0.75 days h, (c) 1.75 days, and (d) 11 days. $84 \times 141 \mathrm{~mm}(1200 \times 1200 \mathrm{DPI})$ 

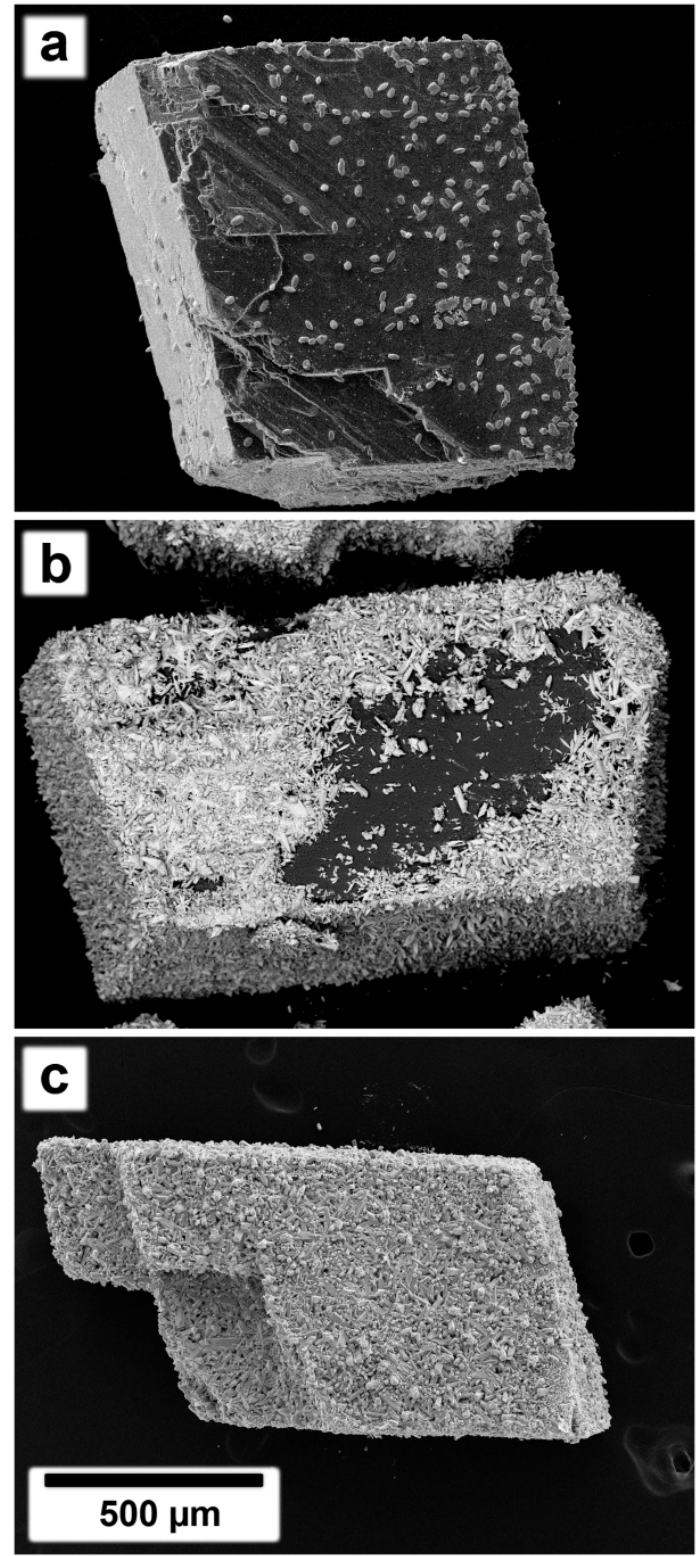

Figure 5.: SEM micrographs of the surface of calcite grains exposed to La-bearing solutions at $95^{\circ} \mathrm{C}$. (a) After 0.75 days of reaction, some crystals of kozoite-(La) are scattered on the surface of calcite. (b) Kozoite(La) crystals quickly cover the available surface after 1.75 days. (b) The full calcite grain is replaced by Kozoite-(La) after 13 days.

$84 \times 191 \mathrm{~mm}(600 \times 600$ DPI $)$ 

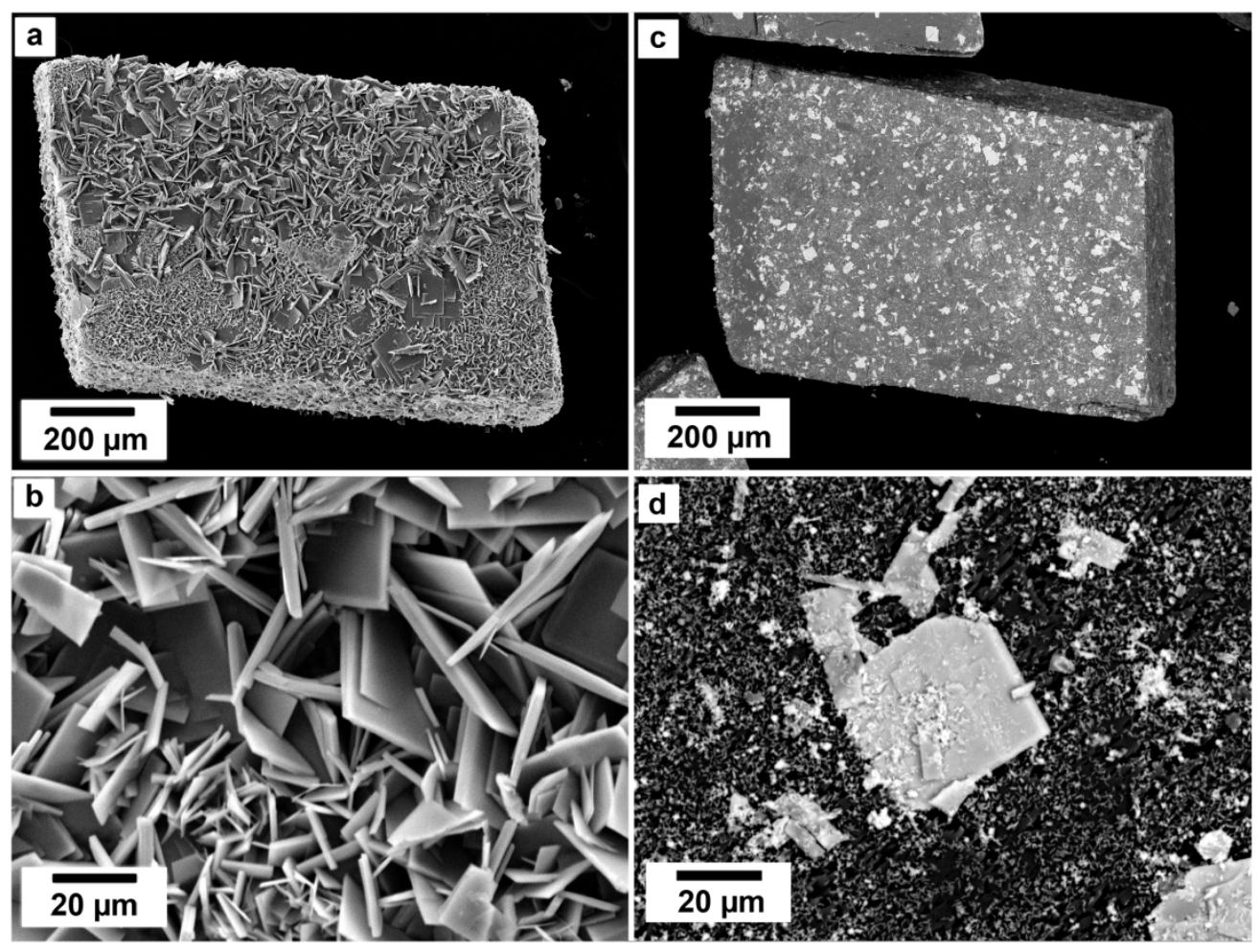

Figure 6.: SEM micrographs showing: (a) The surface of calcite completely covered by lanthanite-(La) after 42 days of reaction (b). Detail of lanthanite-(La) crystal aggregates. (c) Scattered crystals of lanthanite-(Nd) on the surface of calcite after 145 days of reaction. (d) Morphology of lanthanite-(Nd) single crystals.

$84 \times 63 \mathrm{~mm}(600 \times 600$ DPI $)$ 


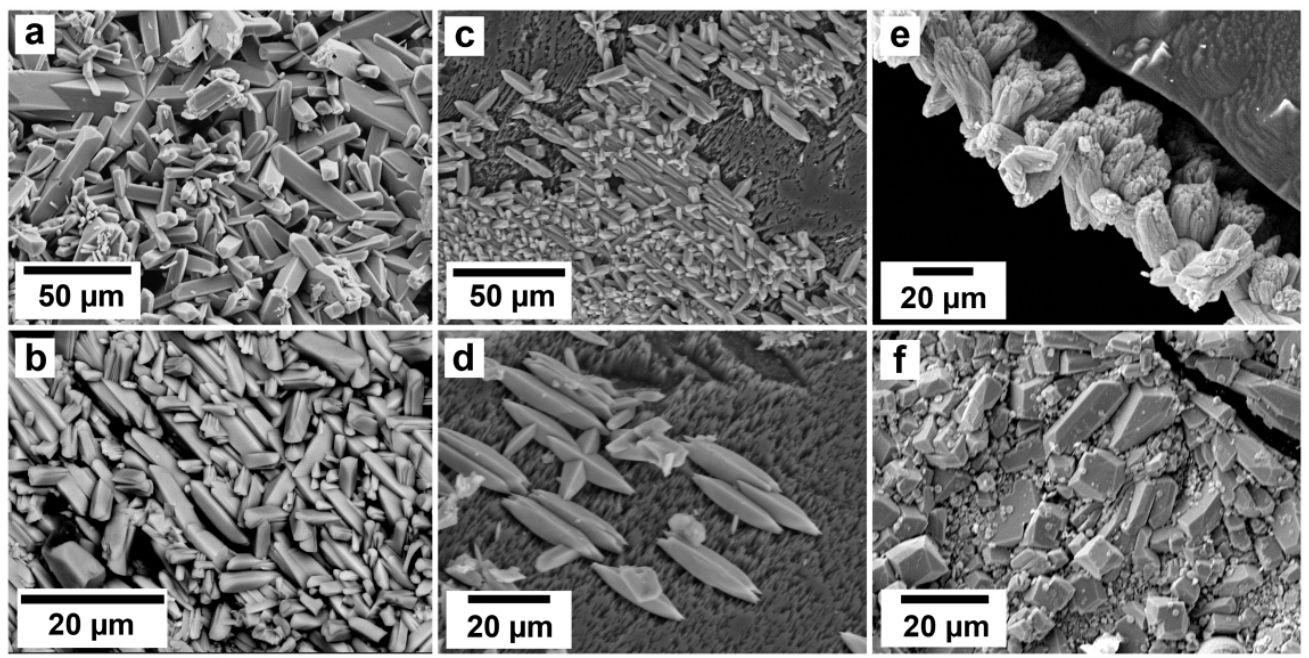

Figure 7: SEM micrographs of (a) newly-formed kozoite-(La) with random orientation of the surface of calcite; (b) kozoite-(La) with some individual crystals oriented on calcite; (c) kozoite-(Nd) oriented on the (104) surface of calcite; (d) detail of single crystals of kozoite-(Nd) oriented on the (104) surface calcite; (e) DyCO3 $(\mathrm{OH})$ overgrowth on calcite (f) $\mathrm{DyCO}_{3}(\mathrm{OH})$ with prismatic shapes crystallised on surface of calcite at $220^{\circ} \mathrm{C}$.

$177 \times 89 \mathrm{~mm}(600 \times 600 \mathrm{DPI})$ 

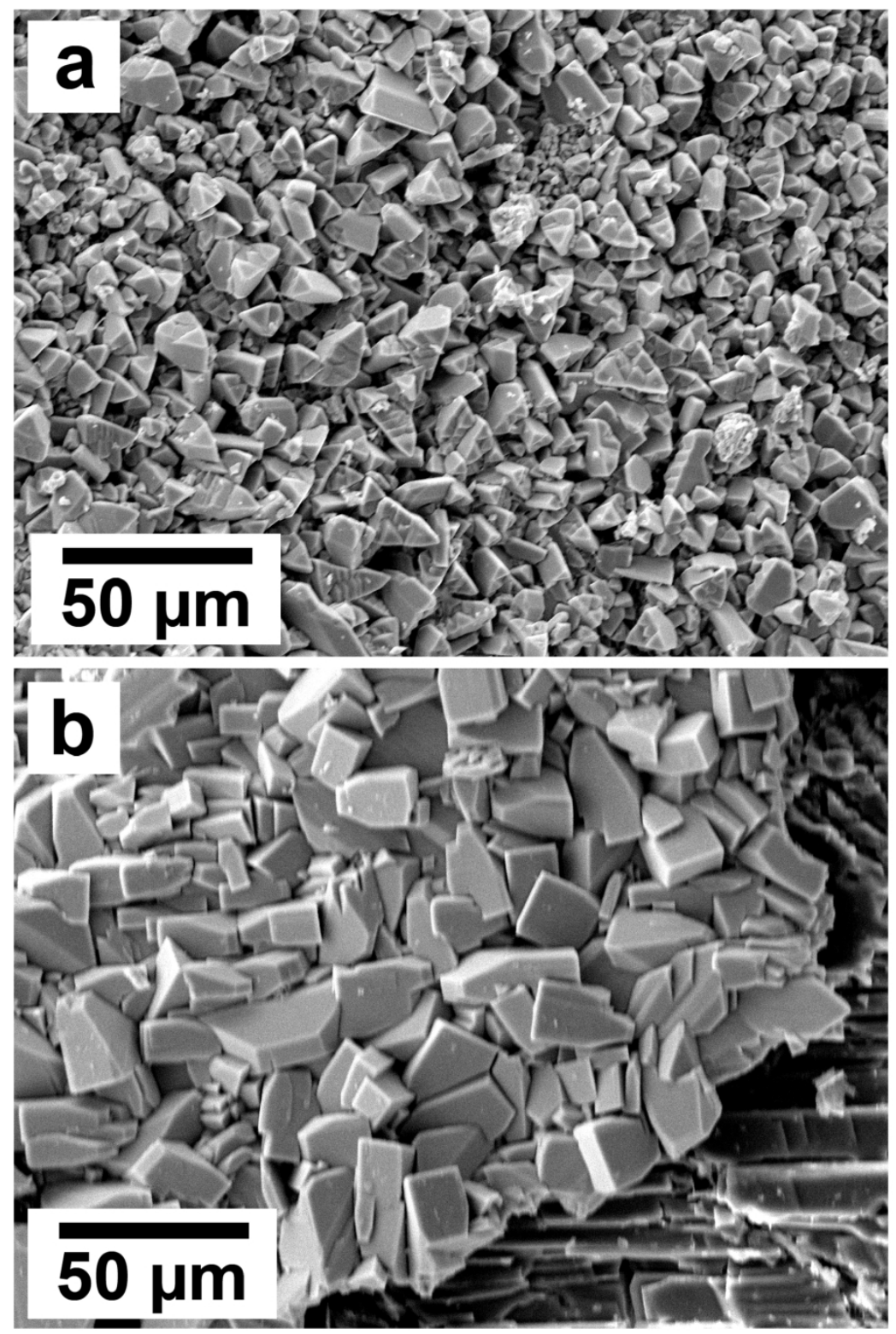

Figure 8: SEM images of (a) newly-formed bastnasite-(La) and (b) bastnasite-(Nd) replacing calcite formed at $220^{\circ} \mathrm{C}$.

$84 \times 127 \mathrm{~mm}(600 \times 600 \mathrm{DPI})$ 

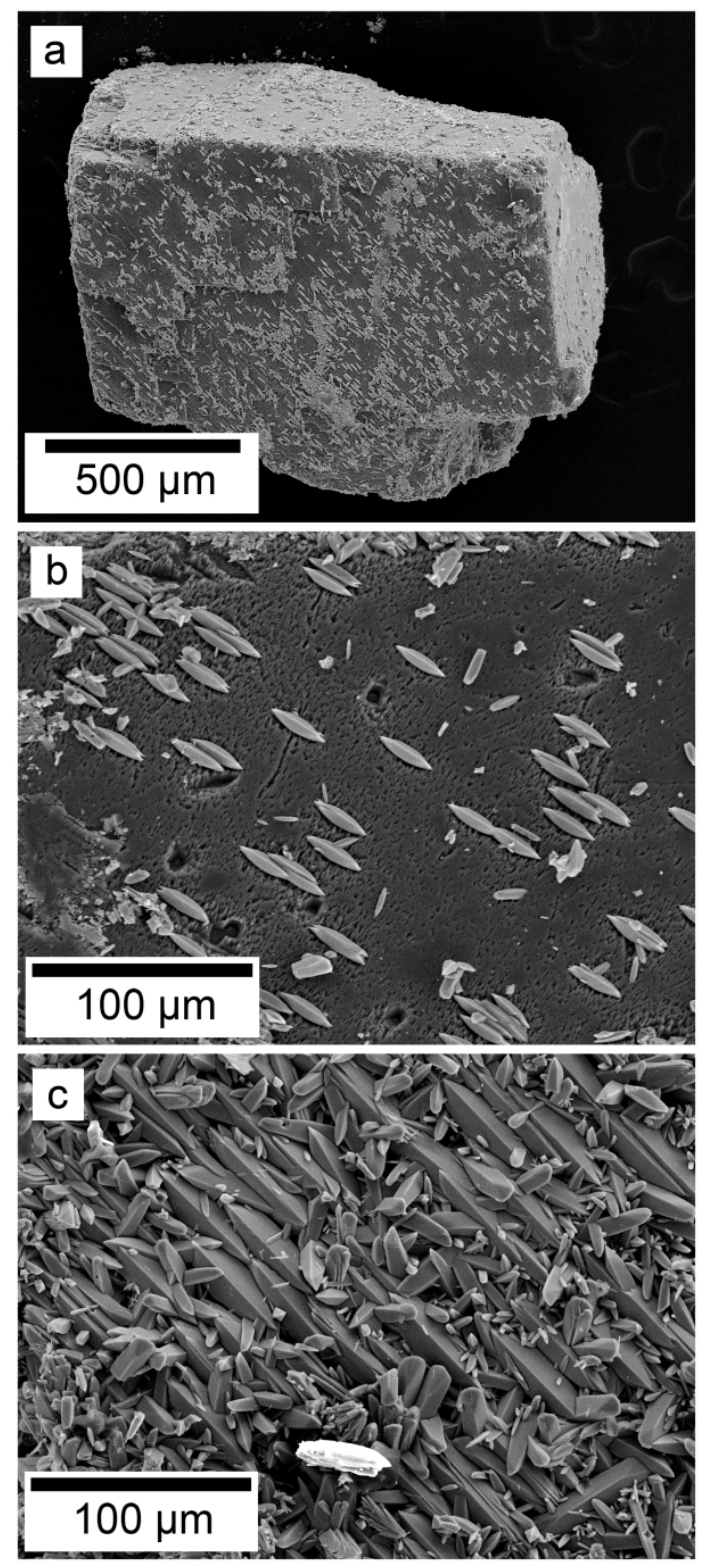

Figure 9: SEM micrographs showing oriented kozoite-(Nd) grown onto the (104) surface of calcite. (a) Overall view of a calcite grain showing the early stages of development of kozoite-(Nd); (b) detail of the calcite surface showing kozoite-(Nd) crystals attached to the calcite surface. (d) Calcite surface completely covered by kozoite-(Nd) crystals.

$84 \times 191 \mathrm{~mm}(600 \times 600 \mathrm{DPI})$ 


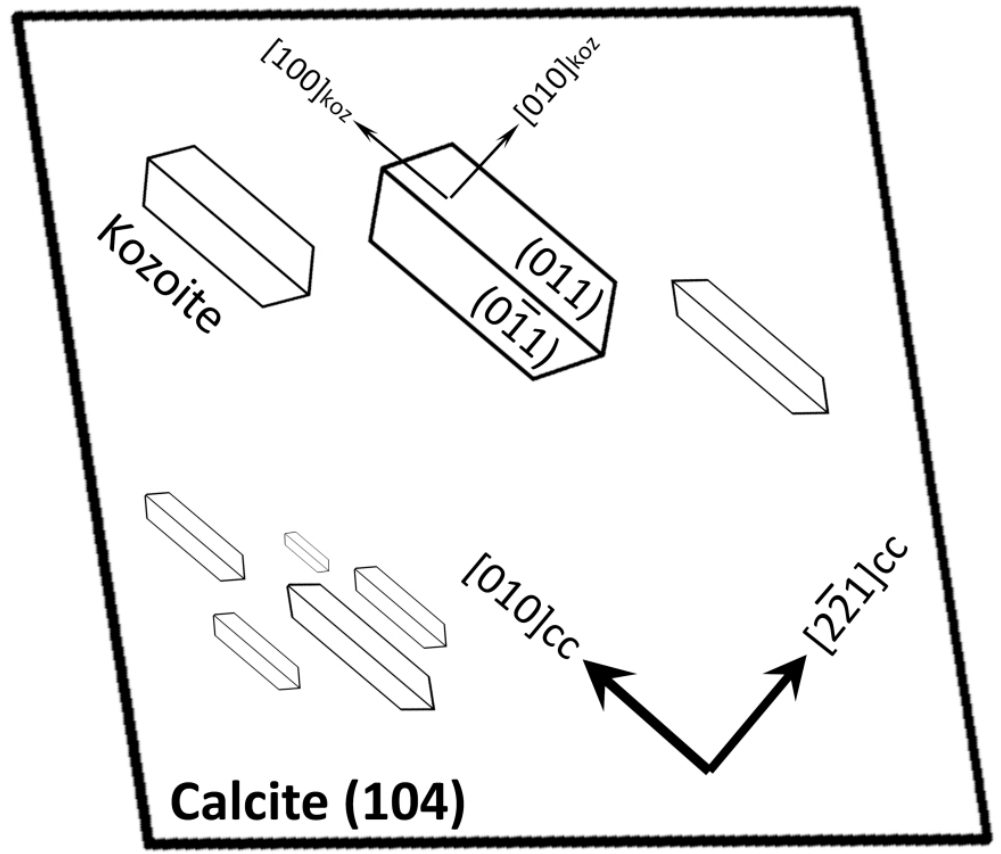

Figure 10: Schematic diagram showing the epitaxial relationship between kozoite and calcite crystals. $84 \times 75 \mathrm{~mm}(1200 \times 1200$ DPI $)$ 
Figure 11: Reaction pathways towards bastnäsite observed during the replacement of calcite by rare earth carbonates. Continuous lines correspond to observed reactions, while dashed lines correspond to expected reactions that were not observed in our experiments. Each line shows the temperature at which the reaction takes place.

$84 \times 61 \mathrm{~mm}(300 \times 300$ DPI $)$ 

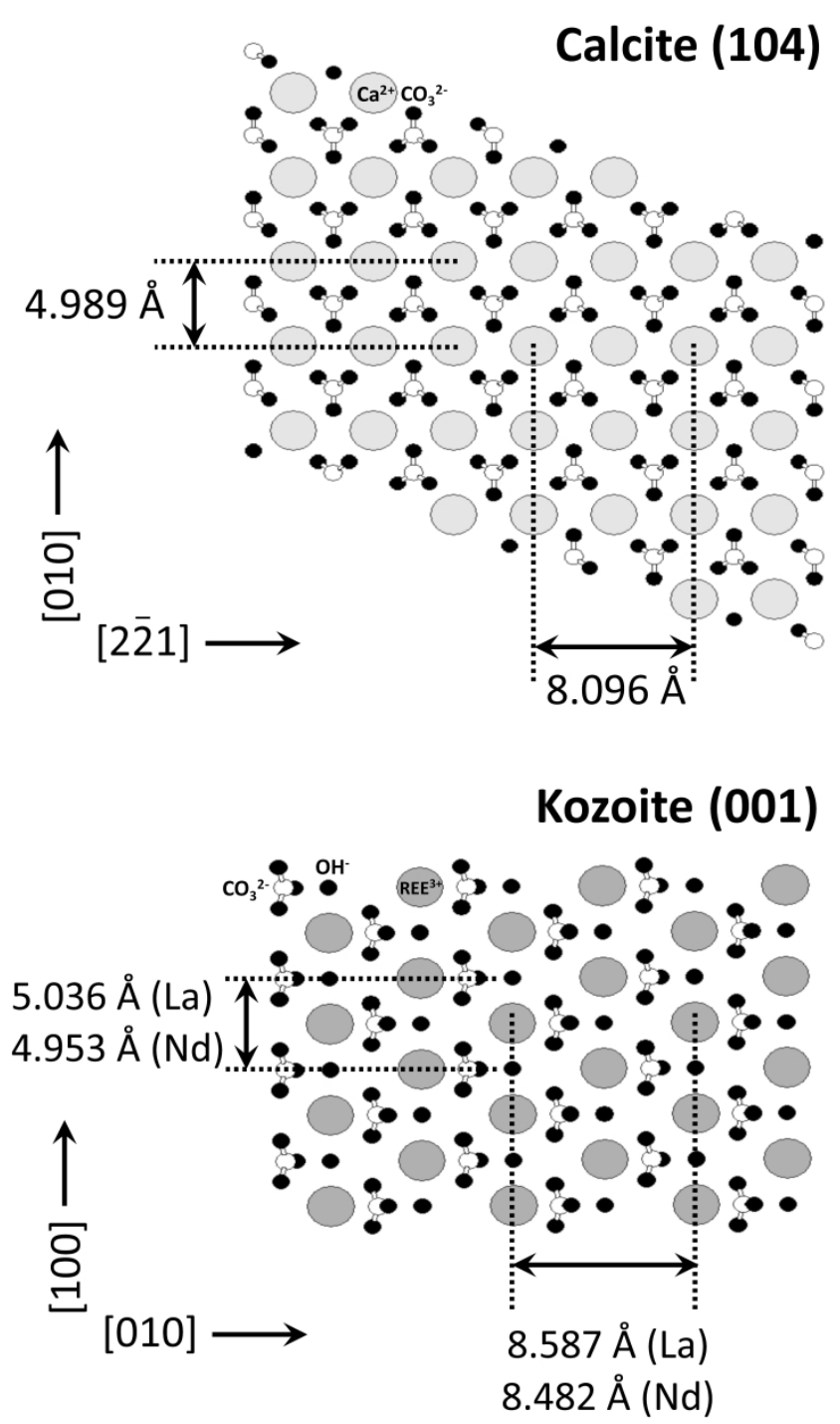

Figure 12: Projection of the crystal structures of a (104) slice of calcite and a (001) slice of kozoite showing the main directions of epitaxy and the repeating periods.

$$
84 \times 150 \mathrm{~mm}(1200 \times 1200 \text { DPI })
$$

